\title{
LA REAPARICIÓN DE LA COSA PERDIDA Y LA FACULTAD DEL ACREEDOR PARA RECLAMARLA*
}

["Lost and Found items and the Right of the Creditor to Claim Found Items"]

\author{
Jaime AlCalde Silva** \\ Pontificia Universidad Católica de Chile, Santiago
}

\begin{abstract}
RESUMEN
El artículo 1675 CCCh. -cuya historia legislativa muestra que en buena medida es original de Bello en el "Proyecto de 1853 ”- supone que la cosa debida se extravió y que el acreedor recibió su precio en sustitución; pero que posteriormente reapareció sin que entretanto se supiera su paradero; y permite al acreedor pretender la cosa reaparecida, restituyendo lo que hubiere recibido en razón de su precio. Tal facultad parece imponer un orden de preferencia entre los remedios al incumplimiento contractual, favoreciendo la pretensión de cumplimiento por sobre
\end{abstract}

\begin{abstract}
Article 1675 CCCh. [Chilean Civil Code]- legislative history of which shows that, to a great extent, Bello is its author in the "1853 Project" - entails that the thing owed got lost and the creditor received the price for it in return, but it subsequently reappeared without knowing its whereabouts in the meantime, and allows the creditor claiming the lost item, by giving back what $s /$ he could have received for its price. Said right seems to impose a preference order among the remedies to the breach of contract, favoring the intent of fulfillment over other mechanisms to
\end{abstract}

${ }^{*}$ Este trabajo es una versión ampliada de la ponencia presentada en las IX Jornadas chilenas de Derecho civil, organizadas por la Universidad Adolfo Ibáñez y celebradas en Viña del Mar los días 4, 5 y 6 de agosto de 2011. Una versión de esa ponencia, con algunos desarrollos y la agregación de las citas esenciales, está publicada en las actas que edita AbeledoPerrot/LegalPublishing.

** Instructor adjunto de Derecho privado de la Pontificia Universidad Católica de Chile. Investigador de la Academia de Derecho Privado UC y del Centro de Gobierno Corporativo UC. Dirección postal: Facultad de Derecho, Pontificia Universidad Católica de Chile, Avda. Bernardo O 'Higgins, Santiago, Chile. Dirección electrónica: jcalcand@uc.cl 
otros mecanismos de satisfacción de interés del acreedor. $\mathrm{Al}$ analizar la norma surgen, empero, una serie de problemas referidos tanto a su supuesto de hecho como a las consecuencias jurídicas que siguen de la reclamación de la cosa reaparecida por parte del acreedor.

\section{Palabras Clave}

Imposibilidad de la prestación Incumplimiento contractual - Pérdida de la cosa debida - Responsabilidad contractual. meet the interests of the creditor. However, when analyzing the rule, a series of problems related to both the occurrence of the event as well as to the juridical consequences following the claim of the reappeared thing by the creditor.

\section{KEYWORDS}

Impossibility of providing the service - Breach of contract - Loss of owed things - Contractual liability.

RECibido el 25 de enero y ACEPTADo el 18 de mayo de 2012.

\section{Planteamiento}

Una de las bases sobre las que se asientan las reformulaciones sobre la responsabilidad contractual es el hecho de que la administración del elenco de remedios existente se independiza de una prelación preestablecida y se entrega al acreedor, quien elegirá aquél que resulte más adecuado para satisfacer su interés, con la posibilidad de combinar cualquiera de ellos con la indemnización de los daños sufridos ${ }^{1}$. En el Código Civil chileno (= CC.), esta libertad de elección viene establecida con carácter general para los contratos bilaterales en el artículo 1489, para las obligaciones de hacer en el artículo 1553 y para las obligaciones negativas en el artículo 1555 . Sólo las obligaciones de dar unilaterales quedan fuera de este esquema y sobre ellas podría existir alguna duda respecto del remedio que ha de ser preferido a otros. Sin embargo, la consideración del principio de fuerza obligatoria del contrato (artículo 1545 CC.) permite desvirtuar cualquier incertidumbre: éste exige que la regla contractual sea respetada como medio de ordenación de la conducta de las partes enderezada a la consecución de un determinado

\footnotetext{
${ }^{1}$ Principalmente, y para el Derecho chileno: Barros Bourie, Enrique, Finalidad $y$ alcance de las acciones y los remedios contractuales, en GUZMÁN BRITO, A. (editor), Estudios de Derecho civil (Santiago, LegalPublishing, 2008), III, pp. 407-408; PizARRO WILSON, Carlos, Hacia un sistema de remedios al incumplimiento contractual, en Guzmán Brito, A. (editor), Estudios de Derecho civil (Santiago, LegalPublishing, 2008), III, p. 400; Vidal Olivares, Álvaro, El incumplimiento de obligaciones con objeto fungible y los remedios del acreedor. Una relectura de las disposiciones del "Código Civil' sobre incumplimiento, en Guzmán Brito, A. (editor), El Código Civil de Chile (1855-2005) (Santiago, Editorial LexisNexis, 2007), pp. 519-522.
} 
propósito práctico. Para esos efectos, es indiferente el mecanismo que se emplee, pues lo verdaderamente relevante es que se satisfaga el interés que el acreedor pensaba alcanzar con el contrato ${ }^{2}$.

La indiferencia sobre aquel remedio que debe ser ejercido con preferencia a otros cuando se ha incumplido una obligación que recae sobre una especie o cuerpo cierto, se complica cuando entra en escena una regla contenida en el título que el Código Civil dedica a disciplinar la pérdida de la cosa debida o, en términos más generales, la imposibilidad de la prestación (título XIX del libro IV). Se trata del artículo 1675 , referido a la reaparición de la cosa extraviada, que parece ser indiciario de una respuesta contraria a la tesis hoy predominante, admitiendo la preeminencia de la pretensión de cumplimiento por sobre los demás remedios al menos en esa clase particular de obligaciones. Mirada con algo de detenimiento, esta norma se ocupa de una situación bastante curiosa, pues permite al acreedor exigir la misma prestación debida aun después de que el deudor ha cumplido con ella en equivalente y, en principio, de que la obligación se ha extinguido merced de esta forma de cumplimiento (artículos 1670 y 1672 CC.). En efecto, el mentado artículo señala: "Si reaparece la cosa perdida cuya existencia se ignoraba, podrá reclamarla el acreedor, restituyendo lo que hubiere recibido en razón de su precio".

El propósito de este trabajo es analizar el material normativo que se entrega en el artículo 1675 CC. y en el resto del título XIX de su libro IV sobre esta curiosa situación relacionada con la pérdida y posterior reaparición de la cosa debida. Comporta, pues, una labor de exégesis enderezada a detectar el supuesto de hecho (III) y los problemas que sugiere una eventual aplicación de esta regla $(\mathrm{IV})^{3}$. Con carácter previo se realizará una breve indagación sobre la historia legislativa de la norma (I), necesaria para comprender su cabal sentido y alcance (artículo 19 inciso $2^{\circ} \mathrm{CC}$ ). Para acabar, se ofrece un pequeño cuerpo de conclusiones $(\mathrm{V})$.

${ }^{2}$ Vidal Olivares, Álvaro, La Convención de Viena (CISG) como clave del debate. La visión del jurista americano, en VV. AA., Derecho privado europeo: estado actual y perspectivas de futuro (Jornadas en la Universidad Autónoma de Madrid, 13 y 14 de diciembre de 2007) (Madrid, Thomson-Civitas, 2008), pp. 449-451, funda la libre elección de los remedios y su administración razonable en el principio de buena fe objetiva (artículo 1546 CC.).

${ }^{3}$ Hasta donde se ha podido comprobar, esta norma no ha sido aplicada por la jurisprudencia. Así se constata de la revisión de Figueroa YÁÑEz, G. (coordinador), Repertorio de legislación y jurisprudencia chilenas. Código Civil y leyes complementarias (3 edición, Santiago, Editorial Jurídica de Chile, 1997), VI, artículo 1675, p. 161, y de las bases de datos de LegalPublishing y Microjuris (ambas consultas por última vez el 31 de octubre de 2011). 


\section{Historia legislativa DEL ARTículo 1675 CC.}

El artículo 1675 CC. aparece tardíamente dentro del elenco de reglas sobre imposibilidad de la prestación, cuya primera redacción se contiene en el "Proyecto de 1842" (título XVIII). En efecto, esta norma sólo es incluida en el "'Proyecto de 1853"” (artículo 1858) y presentaba ahí una redacción casi idéntica a la actual, la que ya puede leerse en el "“Proyecto Inédito"” (artículo 1858). La diferencia existente entre estos dos proyectos sólo consiste en la variación experimentada por el tiempo de la forma verbal de la tercera persona singular en que se conjuga el verbo recibir, que se emplea para designar aquello que se ha atribuido al acreedor en razón del precio de la cosa perdida. En el "Proyecto de 1853", tal verbo venía conjugado en pretérito pluscuamperfecto de subjuntivo ("bubiese recibido"), mientras que en el "Proyecto Inédito" (como hoy en el código) figura en futuro perfecto de igual modo ("bubiere recibido"). A pesar de este cambio en el tiempo gramatical, se trata de una modificación irrelevante que en nada afecta el sentido de la disposición (salvo quizá para resaltar su contingencia o eventualidad futura), dado que en ambos casos se quiere expresar una acción subordinada y fuera del tiempo en que se habla desde el punto de vista del sujeto activo, como es la recepción de aquello que el deudor ha dado al acreedor en reemplazo de la cosa extraviada ${ }^{4}$. Quizá la razón de dicho cambio no sea otra que la variante del español hablada por Bello (1781-1865), pues Venezuela se caracterizó siempre por un uso especialmente abundante, mayor que en cualquier otra área del mundo hispánico, del futuro de subjuntivo ${ }^{5}$; si bien en la actualidad se trata de un tiempo que ha caído en desuso en la lengua oral de todas las áreas lingüísticas, quedando limitada su utilización a textos jurídicos y también, con algunos registros ocasionales, a textos literarios o ensayísticos ${ }^{6}$.

En los proyectos que precedieron al Código Civil no existe ninguna nota que aluda a la fuente del actual artículo 1675 , por lo que su origen se debe buscar a través de la indagación de aquéllas a las que su principal autor

\footnotetext{
${ }^{4}$ Herrero Ruiz de Loizaga, F. J., Cronología y usos del futuro de subjuntivo, en Villayandre LlamaZares, M. (editor), Actas del XXV Simposio internacional de la Sociedad Española de Lingüistica (León, Publicaciones de la Universidad de León, 2006), pp. 941-942; Real Academia Española, Nueva gramática de la lengua española. Manual (Madrid, Espasa Libros, 2010), p. 460; ZuluaGA, A., El futuro de subjuntivo. Observaciones sobre la distinción lengua hablada/lengua escrita y el verbo español, en Bellini, G. (editor), Actas del VII Congreso de la Asociación Internacional de Hispanistas (Roma, Bulzoni, 1982), pp. 1075-1078.

${ }^{5}$ Ramírez Luengo, J. L., Notas sobre el futuro de subjuntivo en la primera mitad del siglo XIX: el caso de Bolivar, en Estudios de Lingüistica, 15 (2001), p. 11.

${ }^{6}$ Real Academia Española, Nueva gramática, cit. (n. 4), pp. 459-460.
} 
probablemente pudo haber recurrido 7 . A este respecto, el "Mensaje" con que fue presentado el código ante el Congreso señala que, en materia de contratos y cuasicontratos, hay pocas materias que no encuentran su fuente en la legislación entonces vigente o en la autoridad de alguno de los códigos en vigor, especialmente el francés $(\$ 36)$.

La primera tarea para acometer el estudio de los antecedentes históricos del artículo 1675 consiste, entonces, en aislar las fuentes jurídicas probables y efectuar su cotejo. De la revisión de las notas puestas por Bello al "Proyecto de 1853 " se verifica que la principal fuente empleada para la composición del título XIX del libro IV fue el Digesto, que aparece citado a propósito de los artículos 1670, 1672, 1676 y 1678 (correspondientes a los artículos 1853, 1855,1859 y 1861 de dicho proyecto). En lo que atañe a las Partidas, ellas figuran como inspiración del artículo 1672 I (artículo 1855 del "Proyecto de 1853”) conjuntamente con el Digesto. Otro texto español citado es la Novisima Recopilación de Leyes de España, que se menciona como antecedente del artículo 1673 (artículo 1856 del "Proyecto de 1853"). Por su parte, el cotejo textual demuestra que el artículo 1675 no tiene correspondencia directa en el Code Civil francés, a diferencia de lo que acaece con los artículos 1670 (artículo 1302 inciso $1^{\circ}$ ), 1672 (artículo 1302 incisos $1^{\circ}$ y $2^{\circ}$ ), 1674 (artículo 1302 inciso $3^{\circ}$ ), 1676 (artículo 1302 inciso $4^{\circ}$ ) y 1677 (artículo 1303). Tampoco existe entre las fuentes romanas un texto que directamente establezca un criterio similar para solucionar el conflicto producido por la reaparición de la cosa extraviada ${ }^{8}$, salvo quizá aquellos relacionados con la captura del esclavo legado o prometido?

La tarea de revisión se ha de extender necesariamente, entonces, a las otras fuentes legales que Bello pudo revisar, sea de forma directa, sea a través de la Concordance entre les codes civils étranger et le Code Napoleon (1840) de Fortune Antoine de Saint-Joseph (1794-1853) ${ }^{10}$.

Los códigos vigentes en aquella época podían agruparse de la siguiente forma según el tratamiento que dispensaban a la pérdida de la cosa debida.

${ }^{7}$ Sobre tales fuentes, véase: GuZMán BRito, Alejandro, Andrés Bello codificador. Historia de la fijación y codificación del Derecho civil en Chile (Santiago, Ediciones de la Universidad de Chile, 1982), I, pp. 421-427; El mismo, La codificación civil en Iberoamérica. Siglos XIX y XX (Santiago, Editorial Jurídica de Chile, 2000), §38, pp. 368373.

${ }^{8}$ Claro Solar, Luis, Explicaciones de Derecho civil chileno y comparado, XII: De las obligaciones, 3 (Santiago, Nascimento, 1939), núm. 1899, pp. 570-571.

${ }^{9}$ Cuena Boy, Francisco, "Rerum natura" e imposibilidad física de la prestación en el Derecho romano clásico (Santiago de Compostela, Andavira, 2010), pp. 182-184.

${ }^{10}$ Se ha utilizado la siguiente edición: SAINT-Joseph, F. A., Concordance entre les codes civils étranger et le Code Napoleon (2 ${ }^{\text {a }}$ edición, París, Cotillon, Libraire du Conseil d'Etat, 1856), cuatro volúmenes. 
a) Un primer grupo se limitaba a reproducir los artículos 1302 y 1303 del Code Civil francés con algunas modificaciones menores en su redacción o disposición. Tal era el caso del Codice Civile per gli Stati di Parma, Piacenza e Guastalla (artículos 1283 y 1284), el Code Civil du Canton de Vaud (artículos 967 y 968), el Code Civil de l'État de la Lousianne (artículos 2216 y 2217), el Code Civil du Canton de Berna (artículos 1023-1025), el Código Civil de Bolivia (artículos 1313-1316), el Codice Civile per gli Stati di S.M. il re de Sardegna (artículos 1393 y 1394), el Code Civil du Canton de Tessin (artículos 661 y 662), el Burgerlijk Wetboek holandés (artículos 1480 y 1481), el Code Civil du Canton de Lucerne (artículos 773 y 774) y el Code Civil du Canton de Fribourg (artículos 1334-1338). De ellos, sin embargo, Bello no podía obtener un texto original y de redacción distinta a la empleada por el Code Civil, pues todos se limitaban a señalar que, cuando la cosa cierta y determinada que era objeto de la obligación perecía, quedaba fuera del comercio o se perdía de modo que se ignorase absolutamente su existencia, la obligación se extinguía si dicha pérdida o perecimiento acaecía sin culpa del deudor y antes de haberse constituido en mora (artículo 1302 inciso $1^{\circ}$ ).

b) Un segundo grupo estaba compuesto por aquellos textos que innovaban la formulación de las reglas sobre pérdida de la cosa debida ofrecida por el código francés, sin que esa novedad supusiera la inclusión de una norma como la que después recogió el artículo 1675 CC. Aquí comparecen el Codex Maximilianeus Bavaricus Civilis (artículo 12 del capítulo $15^{\circ}$ del libro IV) y el Allgemeines Bürgerliches Gesetzbuch austríaco ( $\$ 1447)$.

c) Por último, había ciertos códigos que omitían cualquier tratamiento de la pérdida de la cosa debida como modo de extinguir las obligaciones, como acaecía con el Allgemeines Landrecht für die Preussischen Staaten (1792) y el Codice Civile del Regno delle Due Sicilie (1819).

Teóricamente, Bello contaba además con el Proyecto de Código Civil español de 1851 y los comentarios de Florencio García Goyena (1783$1855)^{11}$, que sí presentan algunas diferencias con la dicción empleada por el Code Civil. En el "Proyecto de 1851", la regla equivalente al artículo 1302 del código francés comportaba un reenvío (que García Goyena hacía expreso en sus comentarios ${ }^{12}$ ) al artículo 1040 inciso $3^{\circ}$, sito en la sección dedicada a

${ }^{11}$ Sobre la influencia de estas fuentes, véase: Lira Urquieta, Pedro, García Goyena y el Código Civil chileno, en El Código Civil chileno y su época (Santiago, Editorial Jurídica de Chile, 1956), pp. 75-98, especialmente pp. 90-91, referidas a los modos de extinguir las obligaciones.

${ }^{12}$ García Goyena, Florencio, Concordancias, motivos y comentarios del Código Civil español (reimpresión de la edición de Madrid, 1852, al cuidado de la Cátedra de Derecho civil de la Universidad de Zaragoza, Zaragoza, Editorial Cometa, 1974), comentario al artículo 1160, p. 616. 
las obligaciones puras y condicionales, que entendía existir pérdida cuando la cosa desaparecía, de modo que se ignorase su existencia o no se pudiese recobrar (artículo 1160 inciso $\left.1^{\circ}\right)^{13}$. Así, para que la obligación efectivamente se extinguiera era necesario o bien que la cosa se perdiera y se ignorase su existencia (como ordenaba el código francés), o bien que tras el extravío no hubiese posibilidad de recuperarla, añadido desde el cual cabía extrapolar una imposibilidad absoluta de carácter temporal o reversible, supeditada a la reaparición de la cosa. Aunque tardíamente dentro del proceso de factura del Código Civil, Bello pudo consultar el "Proyecto de 1851" y los comentarios de García Goyena mientras preparaba el "Proyecto de 1853"14, que es precisamente el momento en que hace su aparición el actual artículo $1675^{15}$. Ahora bien, si verdaderamente estos textos le sirvieron de inspiración para su redacción, es materia sobre la que no existe indicio cierto y que pertenece al campo de la conjetura.

Enseguida, nuestra tarea de reconstrucción histórica exige ocuparse de las fuentes doctrinales disponibles, porque sabemos por el "Mensaje" de presentación del Código Civil que Bello no sólo siguió a su equivalente francés, sino también "la doctrina de alguno de los más eminentes jurisconsultos” (\$36), principalmente Pothier (1699-1772) para el derecho anterior a la codificación y Delvincourt (1762-1831) y Rogron (1793-1871) para la temprana explicación del Derecho francés codificado.

Respecto a ellas, cabe descartar las luces que para la explicación de las normas del Code Civil sobre pérdida de la cosa debida pudieron haber proporcionado a Bello las obras de Delvincourt ${ }^{16}$ y Rogron $^{17}$, pues estos autores no se pronunciaron sobre el supuesto en estudio al tratar de dicho modo de extinguir las obligaciones. Como tampoco la lectura de Domat ${ }^{18}$

${ }^{13} \mathrm{La}$ misma coordinación se ha de hacer actualmente entre los artículos $1122 \mathrm{~N}^{\circ} 2$ inciso $2^{\circ}$ y 1182 del Código Civil español.

${ }^{14}$ GuZmán Brito, A., La codificación civil, cit. (n. 7), §38, p. 370.

${ }^{15}$ El Proyecto de Código Civil español de 1836 contenía una disciplina sobre la pérdida de la cosa debida casi idéntica a la que después recogió el "Proyecto de 1851 ", pero con una particularidad: a propósito del efecto de las obligaciones de dar, se indicaba que el deudor no quedaba sujeto al cumplimiento "si probare que la inejecución resulta de una fuerza mayor imprevista”, de manera que se entendía que la obligación quedaba en suspenso mientras durase tal causa (artículo 933). Sin embargo, este proyecto fue muy probablemente desconocido para Bello.

${ }^{16}$ Delvincourt, C. E., Cours de Code Civil (Paris/Dijon, Videcoq Libraire/Victor Lagier Libraire, 1834), II, pp. 179-180. El desarrollo de la notas respectivas tampoco aporta mayores antecedentes (pp. 585-588).

${ }^{17}$ Rogron, J. A., Code Civil expliqué (Paris, E. Plon et Cie. Imprimeurs-Éditeurs, $19^{\mathrm{a}}$ ed. por E. Bonnier, 1877), I, pp. 1446-1447.

${ }^{18}$ Domat sólo menciona la eficacia extintiva de la pérdida de la cosa debida cuando 
(1625-1696) es un expediente útil para encontrar los antecedentes del artículo 1675 , sólo Pothier puede haber sido de alguna ayuda, dado que él sí se extiende indirectamente sobre la figura.

Pothier ${ }^{19}$ explicaba que una cosa que se ha perdido, de manera que se ignore su paradero, se diferencia muy poco de una que efectivamente ha dejado de existir por perecimiento. El punto en el que ambos supuestos difieren es, precisamente, el relativo al alcance de la extinción de la obligación. Cuando una cosa perece, no cabe duda de que deja de existir con aquella individualidad con la que fue concebida por las partes al contratar y que el deudor se libera definitivamente del deber de cumplir con ella su obligación. Pero no sucede lo mismo cuando la cosa sólo se ha extraviado, pues en tal caso el deudor sólo queda liberado de cumplir mientras la cosa permanezca perdida y no sea habida de ningún modo ${ }^{20}$. A juicio de este autor, pues, esta imposibilidad tenía un alcance meramente temporal y, una vez desaparecido el impedimento, obligaba a cumplir la prestación en los términos acordados (conclusión con fundamento en Dig. 32, 79, 2; 32, 79, 3; 46, 3, 98, 8).

El Code Civil prefirió no ocuparse de este supuesto, y se limitó a equiparar la pérdida de la cosa con ignorancia absoluta sobre su paradero al perecimiento o a su exclusión del comercio (artículo 1302 inciso $1^{\circ}$ ), sin referencia a su posibilidad de reaparición ${ }^{21}$. En el Código Civil chileno, la situación es distinta. En efecto, el supuesto planteado por Pothier está implícito en el artículo 1675 , que trata propiamente de la situación contraria: aquella en que se encuentra el acreedor que ha recibido algo en razón del precio de la

no ha mediado culpa del deudor ni éste se halla constituido en mora, conectando la regla con la suerte de las obligaciones recíprocas. Si la cosa puede ser restituida a su dueño, el citado autor impone a quien la ha encontrado la obligación de devolverla en la medida que sepa o pueda saber quién es, conservándola con la diligencia debida durante el tiempo intermedio entre el hallazgo y la restitución. De no hacerlo, comete robo. El dueño, por su parte, queda obligado a pagar los gastos en que ha incurrido el tercero para dar con él o realizar la devolución. El único indicio cercano al artículo 1675 CC. dice relación con la parte del cargamento que ha sido arrojada de la nave a causa de algún peligro. Cuando se recuperare del todo o en parte los efectos echados, dice Domat, cesará a prorrata la contribución a que se encuentran obligados los dueños de dichos efectos; y si se hubiere hecho ya el repartimiento, habrá de devolverse lo que bajo este concepto se hubiere recibido de más. Véase: Domat, Jean, Las leyes civiles en su orden natural (Barcelona, Imprenta de José Tauló, 1841), $1^{\mathrm{a}}$ parte, lib. I, tit. $2^{\circ}$, sec. $2^{\mathrm{a}}$, núm. 21 (I, p. 153); $1^{\text {a }}$ parte, lib. I, tít. $2^{\circ}$, sec. $7^{\text {a }}$ (I, pp. 161-164); y $1^{\text {a }}$ parte, lib. II, tít. $9^{\circ}$ (II, pp.79-87), especialmente secc. $2^{\text {a }}$, núm. 17 (II, p. 87).

${ }^{19}$ Pothier, Robert-Joseph, Tratado de las obligaciones (trad. de M. C. de las Cuevas, Sao Paulo, Editorial Heliasta, 1993), núm. 656 (p. 411).

${ }^{20}$ Pothier, Tratado de las obligaciones, cit. (n. 20), núm. 656 (pp. 411-412).

${ }^{21}$ Claro Solar, L., Explicaciones, XII, cit. (n. 8), núm. 1899, p. 569. 
cosa perdida, cuando ésta reaparece con posterioridad ${ }^{22}$. Como ha quedado dicho, Pothier nada dijo expresamente sobre este caso y sólo refirió el alcance temporal que comportaba la extinción de la obligación por su subordinación a la permanencia del estado de extravío. Pero en el tratamiento que hace del problema subyace el mismo criterio de solución por el que opta el código chileno y del que extrae la consecuencia formulaba en el artículo 1675. De ahí que no sea aventurado afirmar que la formulación de Bello es original en buena medida y dista de ser tradicional ${ }^{23}$, aunque guarde alguna conexión con las explicaciones del citado autor.

\section{EL SUPUESTO DE HECHO DEL ARTíCULO 1675 CC.}

El artículo 1675 CC. trata el caso de que reaparezca una cosa cuya existencia se ignoraba ${ }^{24}$. Su supuesto de hecho está integrado, entonces, por cuatro elementos: que la prestación consista en una cosa (1), que se ignore si ésta realmente existe (2), que con posterioridad ella reaparezca (3) y que el acreedor decida reclamarla tras dicha reaparición (4).

\section{La prestación debe consistir en una cosa.}

El artículo 1675 CC. señala que la prestación del deudor ha de consistir en una cosa. Cumple determinar, pues, el sentido que tal mención desempeña en el supuesto normativo de la regla en análisis.

El título $19^{\circ}$ del libro IV CC. se estructura a partir del concepto de "pérdida de la cosa que se debe", el que se define con relación a un cuerpo cierto que perece, o porque se destruye, o porque deja de estar en el comercio, o porque desaparece y se ignora si existe (artículo 1670), o bien porque se destruye la aptitud para el objeto a que según su naturaleza o según la convención se había destinado (artículo 1486 inciso $3^{\circ}$ CC.). Este concep-

${ }^{22}$ Bravo, J., De la pérdida de la cosa que se debe (memoria de prueba para optar al grado de Licenciado en la Facultad de Leyes y Ciencias Sociales de la Universidad de Chile, Santiago, Almacén Librero e Imprenta Jordán, 1922), p. 29, considera que el supuesto del artículo 1675 es coincidente con el referido por Pothier, de suerte que si la cosa se ha perdido o desaparecido, el deudor sólo se libera de la obligación mientras continúe perdida o no se encuentre de ningún modo. Por esa razón, critica la ubicación de la norma y sugiere que ella mostraría su correcto sentido si hubiese sido incluida como inciso segundo del artículo 1672.

${ }^{23}$ Claro Solar, L., Explicaciones, XII, cit. (n. 8), núm. 1899, p. 570.

${ }^{24}$ Fueyo Laneri, Fernando, Derecho civil, IV, 2: Obligaciones (Santiago, Imprenta y Litografía Universo, 1958), núm. 613, pp. 198, compara este supuesto con la ausencia que da lugar a la presunción de muerte por desaparecimiento (artículo 80 CC.), cuya declaración también puede ser revertida si el ausente reaparece (artículos 90 y 93 CC.). 
to de perecimiento sólo se puede predicar a cabalidad respecto de aquellas cosas que tienen una cierta materialidad que se pueda destruir estructural o funcionalmente (artículo 565 inciso $2^{\circ} \mathrm{CC}$.), y siempre que ellas hayan sido individualizadas determinadamente en relación con un género concreto (artículo 1508 CC. $)^{25}$. Las obligaciones genéricas, en cambio, son insensibles a la imposibilidad, dado que la pérdida de algunas de las cosas pertenecientes al género no extingue la obligación del deudor mientras subsistan otras con las que cumplir (artículos 1510 CC. y 438 núm. $3^{\circ}$ del Código de Procedimiento Civil). Lo mismo cabe decir de las cosas incorporales, esto es, de los meros derechos (artículo 565 inciso $3^{\circ} \mathrm{CC}$.), que por su propia naturaleza son ajenas a un concepto material de pérdida como el que utilizan los artículos 1486 inciso $3^{\circ}$ y 1670 CC.

La redacción del artículo 1675 CC. también lleva a excluir que su supuesto alcance a las obligaciones de hacer y a las obligaciones negativas. Cualquiera de ellas, por consistir en un hecho que se debe ejecutar u omitir, repugna la posibilidad de que la prestación se pueda perder y se ignore su existencia ${ }^{26}$.

${ }^{25}$ Alessandri Rodríguez, Arturo, Teoría de las obligaciones (reimpresión Santiago, Editorial Jurídica Ediar-ConoSur Ltda., 1988), p. 469; BARCia LeHMANn, R., Lecciones de Derecho civil chileno, III: De la teoría de las obligaciones (Santiago, Editorial Jurídica de Chile, 2008), núm. 95-96, pp. 195-196; BARros Errázuriz, Alfredo, Curso de Derecho civil, II, 1: Trata de las obligaciones en general (4a edición, Santiago, Nascimento, 1932), núm. 194, p. 274; Brantt Zumarán, María Graciela, El caso fortuito y su incidencia en el Derecho de la responsabilidad civil contractual. Concepto y función del caso fortuito en el Código Civil chileno (Santiago, AbeledoPerrot/LegalPublishing, 2010), pp. 173 y 175-176; Bravo, De la pérdida, cit. (n. 22), p. 29; Claro Solar, L., Explicaciones, XII, cit. (n. 8), núm. 1883, pp. 557-558; García MonTERo, C., La imposibilidad de ejecución como forma de extinguir las obligaciones (memoria de prueba para optar al grado de Licenciado en la Facultad de Ciencias Jurídicas y Sociales de la Universidad de Chile, Santiago, 1942), núm. 15, pp. 21-22; Guzmán BRITo, Alejandro, Destrucción y especificación de una cosa corporal, en Guzmán Brito, A. (editor), Estudios de Derecho civil (Santiago, LegalPublishing, 2008), III, p. 283; MEZA BArros, Ramón, De las obligaciones (10ª edición por Pedro Pablo Vergara Varas, Santiago, Editorial Jurídica de Chile, 2007), núm. 678, p. 225; VIAL Del Río, Víctor, Manual de Derecho de las obligaciones en el Código Civil chileno (2a edición, Santiago, Editorial Biblioteca Americana, 2007), núm. 130, p. 372. En el mismo sentido, una sentencia de la Corte de Apelaciones de Valparaíso, de 14 de noviembre de 1927, en Revista de Derecho y Jurisprudencia, 26 (1929), secc. 1ª, p. 677 (considerando 10º, p. 681).

${ }^{26}$ En las obligaciones de hacer y no hacer cabe hablar de cierta reaparición si deja de existir el impedimento que afectaba la ejecución del hecho debido o la observancia de la abstención. Es más, el artículo 1555 CC. caracteriza precisamente la destrucción de la cosa hecha por incumplimiento de una obligación negativa como una verdadera modalidad de cumplimiento, y no como un supuesto de reparación (como lo es aquella destrucción implícita en el artículo 2002 inciso $2^{\circ}$ CC.). En esta clase de obligaciones, 
Estas obligaciones ciertamente pueden verse afectadas por un impedimento de la prestación, pero tal ocurre cuando existe una imposibilidad absoluta, moral o física, de ejecutar la obra debida (artículos 1461 inciso $3^{\circ}$ CC. y 534 CPP.), o cuando con la misma radicalidad el deudor queda forzado a ejecutar aquel hecho que la obligación impedía realizar (arg. ex artículo 534 CPC. $)^{27}$.

Ahora bien, las obligaciones referidas a cosas determinadas pueden tener efectos traslaticios o constitutivos o bien simplemente comportar una cesión temporal con eficacia restitutoria posterior ${ }^{28}$. La redacción del artículo 1675 CC. no parece excluir ninguno de los dos supuestos, porque en ambos la pérdida de la cosa debida da lugar a una indemnización de perjuicios fundada en el interés contractual positivo del acreedor, de suerte que la diferencia entre uno y otro caso solamente vendrá dada por la concreta determinación del daño sufrido. Asimismo, la norma se aplica indistintamente a las obligaciones nacidas de contratos unilaterales y bilaterales, puesto que el código únicamente se ocupa de la imposibilidad materialmente considerada y de la valoración y consecuencias jurídicas que ella pueda tener, dejando para otra sede la suerte de la obligación recíproca cuando una de las prestaciones de un contrato bilateral se ha hecho imposible de cumplir (artículo 1550 CC.).

Asumido esto, hay que determinar en qué contratos tiene cabida el supuesto del artículo $1675 \mathrm{CC}$. Entre los contratos unilaterales cabe incluir el comodato (artículos 2174 y 2180 CC.), el depósito (artículos 2211 y 2228 CC.), la prenda (artículos 2384 y 2401 CC.) y la anticresis (artículos 2435

lo directamente debido por el deudor es una abstención, de suerte que lo malhecho es en sí mismo el incumplimiento (artículo 1557 CC.). Si es así, la subsistencia de aquello que se ha ejecutado no debiendo hacerse es absolutamente incompatible con el cumplimiento de la obligación, por lo que éste no puede existir sin que previamente medie la destrucción. Por eso, ésta comporta un paso previo, pero indisolublemente ligado a él, del cumplimiento forzoso de la prestación, que consistirá en mantener esa situación de statu quo que se perseguía al configurar determinada abstención como deseable. Al respecto: Verdera SERVER, R., El cumplimiento forzoso de las obligaciones (Bolonia, Publicaciones del Real Colegio de España, 1995), pp. 90-93.

${ }^{27}$ Por todos: Brantt Zumarán, M. G., El caso fortuito, cit. (n. 25), pp. 173-174 y 176-179.

${ }^{28}$ Malaurie, M. ${ }^{a}$, Les restitutions en Droit civil (Paris, Cujas, 1991), pp. 35-37, menciona la existencia de dos grandes tipos de restituciones: normales y anormales. En las primeras, la restitución está determinada por el título con que el deudor detenta la cosa, lo que significa que ella forma parte de la previsión de las partes. Se trata, por tanto, de una restitución perfecta, que se realiza en cumplimiento de aquello que previamente se había acordado y por el avenimiento del evento establecido para el nacimiento del deber de restituir. Por su parte, la restitución anormal no siempre es integral y su medida dependerá generalmente del enriquecimiento injusto que haya experimentado el deudor. 
y 2444 CC.), que generan para el deudor una obligación de entregar (restitución normal); y excluir el mutuo, porque la obligación que surge para el mutuario es de restituir cosas genéricas (artículos 2196 y 2198 CC.).

En los contratos bilaterales ha de hacerse, en tanto, una distinción a partir del significado de la obligación del deudor. Así, es posible diferenciar entre contratos que generan obligaciones de dar y contratos que sólo producen una obligación de entregar ${ }^{29}$. Pertenecen al primer grupo: $i$ ) la compraventa (artículos 1793 y 1824 CC.); ii) la permuta (artículos 1897 y 1900 CC.); iii) la sociedad, si el socio hace su aporte en dominio (artículos 2053, 2055 y 2083 CC.); y iv) la transacción en lo que atañe al objeto no disputado (artículo 706 inciso $6^{\circ} \mathrm{CC}$.). En el segundo grupo comparecen: $i$ ) el arrendamiento, que origina una obligación de entregar tanto para el arrendador (artículos 1915 y $1924 \mathrm{~N}^{\circ} 1^{\circ} \mathrm{CC}$.) como para el arrendatario (artículo 1947 CC.); $i$ ) la sociedad, de la que nace una obligación de entregar para el socio respecto a su aporte cuando éste consiste en un usufructo (artículo 2053, 2055 y 2082 CC.), y en todo caso una obligación restitutoria de la sociedad

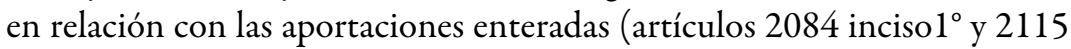
CC.); y iii) la transacción en lo que se refiere a la cosa disputada (artículo 706 inciso $6^{\circ}$ CC.).

No parece discutible que el artículo 1675 CC. se aplique a los casos identificados de obligaciones de dar. Quizá alguna duda pueda existir respecto de la obligación de dar que compete al socio cuando ha comprometido su aporte en dominio, pero ella se despeja con la lectura de las normas aplicables. Para los aportes de esta clase, el peligro de la cosa pertenece a la sociedad desde su recepción según las reglas generales, y ésta queda exenta de la obligación de restituir en especie (artículo 2084 inciso $1^{\circ}$ CC.). Además, la sociedad subsiste aunque la cosa perezca, a menos que sin ella no pueda continuar útilmente (artículo 2102 inciso $1^{\circ}$ CC.). De esta forma, la pérdida de la cosa aportada no tiene consecuencias para la sociedad, salvo que ella sea esencial para su continuación, pero el socio queda responsable de resarcir los perjuicios que de ello se sigan (artículo 2093 CC.). De esta disciplina cabe concluir que, si reaparece la cosa extraviada y a la sociedad le interesa que ella pase a formar parte del haber social, puede hacer uso del artículo 1675 CC. para reclamarla.

Respecto de las obligaciones de entregar, los casos dudosos se reducen a los contratos de sociedad y de arrendamiento, en este último, en lo que

${ }^{29}$ Sólo se analizan los casos más representativos, dejando fuera otros supuestos posibles (por ejemplo, la restitución a la que viene obligado el mandatario respecto de aquellos bienes que le ha proporcionado el mandante para la ejecución del encargo). 
dice relación con la obligación del arrendador ${ }^{30}$. En los demás supuestos, el artículo 1675 CC. se aplica sin reservas.

En el contrato de sociedad, la aportación del socio puede consistir en un usufructo (artículo 2083 CC.), y entonces la pérdida o deterioro de la cosa, no imputable a culpa de la sociedad, pertenecerán al socio que hace el aporte (artículo 2084 inciso $2^{\circ} \mathrm{CC}$.). Cuando eso ocurre, la pérdida de la cosa fructuaria disuelve además la sociedad, a menos que el socio aportante la reponga a satisfacción de los consocios, o que éstos determinen continuar la sociedad sin ella (artículo 2101 inciso $2^{\circ} \mathrm{CC}$.). La regla general es, por consiguiente, que esa pérdida pone fin a la sociedad, soportando el socio respectivo sus consecuencias. Pero también cabe que los demás socios decidan que aquél reponga la cosa aportada o bien que la sociedad continúe sin ella, sin perjuicio de la acción indemnizatoria que les compete contra el socio que ha sido culpable de la pérdida (artículo 2093 CC.). Esta disciplina parece comportar la exclusión del artículo 1675 , dado que del perecimiento de la cosa se siguen unos efectos claramente determinados: la disolución de la sociedad o su continuación, sea con una cosa nuevamente aportada por el socio a quien pertenecía la perecida (el único equivalente funcional de pago que el código acepta), sea sin ninguna.

Por su parte, el arrendamiento es un contrato que se celebra con el deseo de proveerse de un bien del que se quiere gozar o de una obra o servicio del que se tiene necesidad (artículo 1915 CC.). De ahí que la destrucción de la cosa antes de que sea entregada al arrendatario hace que se frustre el propósito práctico que con el contrato se perseguía satisfacer, y que el Código Civil conceda un mecanismo idóneo para restablecer el equilibrio de posiciones entre las partes. En efecto, si el arrendador por hecho o culpa suya o de alguna de las personas a su cargo se ha puesto en la imposibilidad de entregar la cosa, el arrendatario tendrá derecho para desistir del contrato, con indemnización de perjuicios (artículo 1925 inciso $1^{\circ} \mathrm{CC}$.). En cambio, cuando el perecimiento es fortuito, el contrato simplemente expira (artículo $1950 \mathrm{~N}^{\circ} 1^{\circ}$ ). El artículo 1675 CC. no resulta aplicable, dado que la individualidad de la cosa arrendada es generalmente determinante en la continuación del contrato y no cabe un cumplimiento mediante un equivalente funcional.

\section{Se ha de ignorar si la cosa debida realmente existe.}

El segundo requisito mencionado en el artículo 1675 CC. se refiere a la ignorancia sobre la existencia de la cosa o, más bien, a la ignorancia de que esa inexistencia era sólo una cuestión temporal. Esta precisión es importante

${ }^{30}$ La obligación restitutoria del arrendatario no se aparta del régimen general existente en la materia (artículo 1947 CC.). 
de cara al artículo 1670 CC. En él se señala que la cosa debida se entiende perecer, entre otros casos, cuando "desaparece y se ignora si existe", y que ese perecimiento produce la extinción de la obligación (artículo $1567 \mathrm{~N}^{\circ} 7^{\circ}$ CC. $)^{31}$. Sin embargo, la propia norma se encarga de aclarar que esta extinción es sin perjuicio de "las excepciones de los artículos subsiguientes", de donde se sigue que para el código existe una desaparición que sí tiene efectos extintivos (artículo 1670 CC.) y otra que no los produce (artículo 1675 CC.) ${ }^{32}$.

La ley considera perdido el cuerpo cierto cuando ha desaparecido y se ignora si existe (artículo 1670 CC.). Sin embargo, tal desaparición sólo tiene una eficacia extintiva de la obligación cuando el extravío de la cosa, la ignorancia de su paradero y la incertidumbre de su existencia llevan a pensar fundadamente que la cosa ha perecido, exactamente como si se hubiera destruido materialmente ${ }^{33}$. A este supuesto se equiparan los casos en que la cosa ha sido robada o apropiada por cualquier otro tipo de privación ilegal, cuando la pérdida sea definitiva, lo que ocurrirá desde el momento en que ya no quepa abrigar esperanzas sobre su recuperación ${ }^{34}$. Aunque el código no la contemple expresamente, cabe agregar asimismo aquella situación que acaece cuando la cosa queda fuera del alcance material del deudor, por ser imposible su recuperación, aunque se conozca su paradero (el ejemplo clásico de esta imposibilidad práctica es el del anillo que cae en el fondo de un lago, citado incluso por la Exposición de motivos de la Ley de modernización del derecho de obligaciones, de 26 de noviembre de 2001, para ilustrar el supuesto contenido en el nuevo $\$ 275$ inciso $2^{\circ}$ BGB. $)^{35}$. Cuando esto ocurre, el deudor queda imposibilitado para disponer de la cosa, asemejándose tal impedimento a la idea objetiva de perecimiento empleada por la ley. Se observa,

${ }^{31}$ El Código Civil presume, entonces, el carácter irrealizable de la prestación por el extravío de la cosa en que ella consiste. Al ignorarse su existencia, hay antecedentes suficientes para suponer que ese bien ha perecido efectivamente y que, en consecuencia, se ha de proceder como si así hubiese ocurrido (el paso siguiente será establecer la causa del extravío, para determinar sus efectos). Pero nada impide que el acreedor destruya esta presunción y demuestre que, en verdad, la cosa extraviada todavía existe.

${ }^{32}$ Barcia Lehmnn, Lecciones, cit. (n. 25), III, núm. 99, pp. 199-200; Bravo, De la pérdida, cit. (n. 22), p. 34; Fuentealba Chávez, D., Estudio sobre el caso fortuito y la fuerza mayor (memoria de prueba para optar al grado de Licenciado en la Facultad de Leyes y Ciencias Políticas de la Universidad de Chile, Valparaíso, Imprenta Porteña, 1919), p. 49; Meza Barros, R., De las obligaciones, cit. (n. 25), núm. 681 (p. 226) y 691 (pp. 228-229).

${ }^{33}$ Claro Solar, L., Explicaciones, XII, cit. (n. 8), núm. 1899, p. 568; García Montero, La imposibilidad, cit. (n. 25), núm. 32, p. 42.

${ }^{34}$ Castilla Barea, M., La imposibilidad de cumplir los contratos (Madrid, Dykinson, 2000), p. 51.

${ }^{35}$ Fueyo Laneri, F., Derecho civil, IV, 2, cit. (n. 24), núm. 613, p. 198. 
entonces, una correspondencia entre este concepto técnico de pérdida y el artículo 727 CC., según el cual la posesión de una cosa mueble no se entiende perdida mientras se halle bajo la esfera de control del poseedor, aunque éste ignore accidentalmente su paradero ${ }^{36}$. De igual modo, la cosa sigue siendo debida en tanto no salga de poder del deudor, porque hasta que eso ocurra se entiende que conserva la posesión sobre aquélla y puede, obrando con la debida diligencia, procurarse su tenencia para cumplir.

El artículo 1675 CC. trata, por ende, de una cuestión diferente de la relativa a la imposibilidad temporal, que puede o afectar la prestación en sí misma o sólo comportar la desactivación de la facultad del acreedor para exigir su cumplimiento. El primer caso ocurre cuando el retraso priva al acreedor del propósito práctico perseguido con el contrato, y a ella se atribuye un efecto extintivo del deber de prestar (artículo 1486 inciso $3^{\circ} \mathrm{CC}$.) ${ }^{37}$. Por el contrario, cuando el retardo no tiene esa incidencia en el programa de prestación, su efecto es distinto: constituye una causa de inexigibilidad de la obligación mientras el impedimento que la afecte no cese (arg. ex artículo 1558 inciso $2^{\circ}$ CC.) y subsista el interés del acreedor por exigirla (arg. ex artículo 1486 inciso $3^{\circ} \mathrm{CC}$.), de suerte que el deudor queda obligado a cumplir con la misma cosa debida tan pronto haya desaparecido la imposibilidad, pero sin indemnización moratoria (artículos 1557 y 1558 inciso $2^{\circ} \mathrm{CC}$. $)^{38}$.

Cualquiera de estas dos situaciones comprendidas en la imposibilidad temporal atañe a la perturbación que puede sufrir el programa de prestación en el momento de ser cumplido y las reglas antedichas concurren a solucionar el conflicto de intereses que entonces se produce ${ }^{39}$. En cambio, el artículo 1675 parte de la base de que la imposibilidad ya afectó el cumplimiento de

${ }^{36}$ Manresa y Navarro, J. M.. , Comentarios al Código Civil español (Madrid, Imprenta de la Revista de Legislación, 1901), VIII; p. 318.2

${ }^{37}$ Por todos: BARros Bourie, E., La diferencia entre "estar obligado" y "ser responsable” en el Derecho de los contratos, en Corral, H.- Rodríguez, M. a S. (editores), Estudios de Derecho civil (Santiago, Editorial LexisNexis, 2007), II, p. 744.

${ }^{38}$ Abeliuk Manasevich, René, Las obligaciones (4a edición, Santiago, Editorial Jurídica de Chile, 2001), II, núm. 1202, pp. 1058-1059; BARCia LeHMANn, Lecciones, cit. (n. 25), III, núm. 99, pp. 199-200; BRANTt ZumaráN, M. G., El caso fortuito, cit. (n. 25), pp. 180-181; Claro Solar, L., Explicaciones, cit. (n. 8), XII, núm. 1899, p. 569; Fueyo Laneri, F., Derecho civil, cit. (n. 24), IV, 2, núm. 610, p. 193; García Montero, La imposibilidad, cit. (n. 25), núm. 39, p. 52; Meza Barros, R., De las obligaciones, cit. (n. 25), núm. 691, p. 228; Rodríguez Grez, Pablo, Extinción no convencional de las obligaciones (Santiago, Editorial Jurídica de Chile, 2008), p. 129.

${ }^{39}$ Además, por regla general la imposibilidad transitoria únicamente puede ser fortuita, pues de lo contrario existiría simplemente un incumplimiento del deudor y se desencadenarían sus consecuencias propias [CASTILla BAREA, La imposibilidad, cit. (n. 35), pp. 180-181 y 184-186]. 
la obligación, y que lo hizo porque se ignoraba la existencia de la cosa debida (existencia de la que se tenía ciencia cierta al contratar). Al momento de cumplir, el deudor estaba seguro de que esa cosa ya no existía o, al menos, de que no se sabía cuál era su paradero para poder recuperarla ${ }^{40}$. Queda consumado así un supuesto de imposibilidad absoluta (aunque de eficacia reversible) y se desencadenan los efectos propios que el Código Civil atribuye según cual fuere la causa de esa imposibilidad ${ }^{41}$.

3. La cosa tiene que reaparecer con posterioridad a que el deudor haya cumplido con su obligación de una forma distinta a la pactada, pero legalmente permitida. Los equivalentes funcionales del pago.

a) Para el Código Civil no es indiferente el momento en que la cosa reaparece, y prueba de ello es que la regla del artículo 1675 supone un conflicto cierto entre el interés específico del acreedor y aquel del deudor a considerarse liberado de la obligación, el que sólo se produce con posterioridad a que este último hubo cumplido en cierta forma con su prestación. El criterio para solucionar este conflicto de intereses no deja de ser controvertido. Basta considerar, por ejemplo, que Giorgi (1836-1915) $)^{42}$, en ausencia de una norma expresa en el Codice Civile de $1865^{43}$, era partidario de resolver éste asumiendo como premisa que la obligación no podía resucitar si el acreedor, reputándola extinguida, ejerció acciones o derechos contra terceros (artículo 1677 CC.), o se sirvió de expedientes incompatibles con el posterior ejercicio de la pretensión de cumplimiento, como acaece cuando ha recibido el pago

${ }^{40}$ Fueyo Laneri, F., Derecho civil, cit. (n. 24), IV, 2, núm. 613, pp. 197-198, explica que la desaparición debe ser presuntiva de verdadera pérdida, de guisa que la ignorancia sobre si existe todavía la cosa ha de ser precisamente confirmatoria de su desaparición efectiva, y en caso alguno de falta de diligencia en dejar perder aquélla o en buscarla como es debido.

${ }^{41}$ Castilla Barea, La imposibilidad, cit. (n. 37), p. 165, parece apuntar en esta misma dirección cuando señala que "tampoco puede decirse que el impedimento que causa la imposibilidad definitiva dure siempre y el que causa la transitoria sólo sea temporal".

${ }^{42}$ Giorgi, J., Teoría de las obligaciones en el Derecho moderno, VIII: Extinción de las obligaciones (continuación y fin) (trad. de la Redacción de la Revista General de Legislación y Jurisprudencia, 2a edición, Madrid, Editorial Reus, 1930), núm. 140, p. 210.

${ }^{43}$ El Codice Civile de 1942 sí contiene una regla referida a la cosa perdida que es nuevamente habida (artículo 1257 inciso $2^{\circ}$ ). Sin embargo, la situación no es exactamente coincidente con aquella del artículo $1675 \mathrm{CC}$. chileno y más bien guarda relación con la imposibilidad temporal de cumplir. Así se demuestra por el hecho de que la reaparición de la cosa perdida hace aplicable la norma sobre imposibilidad temporal, de suerte que el deudor queda obligado a cumplir su prestación con ella y sólo se libera de la responsabilidad por la mora (artículo 1256 inciso $2^{\circ}$ ). 
en equivalente de la prestación devenida imposible (artículos 1672, 1673, 1676,1678 y 1679 CC.).

En la situación descrita en el artículo 1675 no ha existido un pago en el sentido técnico del término (artículo 1568 CC.), pero el acreedor ha recibido en lugar de la prestación un equivalente que para la ley está dotado de un poder liberatorio equivalente ${ }^{44}$. De estos equivalentes funcionales de cumplimiento trata el mismo título $19^{\circ}$ del libro IV CC., y lo hace distinguiendo tres situaciones bien determinadas, a saber: $i$ ) que la cosa debida perezca durante la mora o por culpa del deudor o de alguna de las personas por quienes éste fuera responsable; ii) que el deudor no haya de responder del perecimiento, pero tal se deba al hecho de un tercero; y iii) que la cosa se destruya por un hecho involuntario del deudor, que inculpablemente ignoraba la existencia de la obligación. El análisis de cada uno de estos supuestos reviste importancia porque guarda estrecha relación con la exigencia impuesta por el artículo 1675 CC. para que tenga éxito la reclamación de la cosa reaparecida.

Con carácter previo, conviene tener presente que la mentada norma parece excluir de su ámbito de aplicación la imposibilidad fortuita ${ }^{45}$. En efecto, ésta tiene como consecuencia que la obligación se extingue sin que el acreedor reciba nada a cambio (artículos $1567 \mathrm{~N}^{\circ} 7^{\circ}$ y 1670 CC.), dando paso paralelamente a la regla legal de distribución del riesgo del artículo 1550 CC. si se trata de un contrato bilateral. Por el contrario, el artículo 1675 requiere que el acreedor haya recibido algo en razón del precio de la cosa perdida, lo que sólo puede ocurrir cuando se está en presencia de alguno de los tres casos antes mencionados ${ }^{46}$.

Cierto es, con todo, que el cambio gramatical introducido por Bello entre el "Proyecto de 1853" y el "Proyecto Inédito" induce a pensar de manera distinta. En la redacción definitiva del artículo 1675, la referencia al pago que recibe el acreedor en razón de la cosa perdida viene expresada a través del futuro perfecto de subjuntivo, tiempo que para Bello denotaba un carácter hipotético ${ }^{47}$. Esta calificación supuestamente comportaría que la mención a

${ }^{44}$ Pugliatti, S., Esecuzione forzata e Diritto sostanziale (Milano, Giuffrè, 1935), núm. 3, pp. 19-20.

${ }^{45}$ Bravo, De la pérdida, cit. (n. 22), p. 29; García Montero, La imposibilidad, cit. (n. 25), núm. 39, p. 52.

${ }^{46}$ Así, pero sólo con relación a la pérdida imputable al deudor, ABELIUK MANASEVICH, R., Las obligaciones, cit. (n. 38), II, núm. 1202, pp. 1058-1059; Claro Solar, L., Explicaciones, cit. (n. 8), XII, núm. 1899, pp. 569-570; García Montero, La imposibilidad, cit. (n. 25), núm. 39, p. 52; RodríGUEZ GrEZ, P., Extinción no convencional, cit. (n. 38), p. 129.

${ }^{47}$ Bello López, Andrés, Obras completas, IV: Gramática de la lengua castellana destinada al uso de los americanos ( $3^{a}$ edición, Caracas, La Casa de Bello, 1994), núm. 658-668 (pp. 188-192). 
la recepción de aquello que se da en vez de la cosa extraviada es un elemento hipotético en la formulación de la regla, de donde se seguiría que bien podría haberse producido o no. En otras palabras, la restitución que la norma ordena vendría condicionada por el hecho de que el acreedor hubiese recibido algo en su oportunidad en lugar de la cosa que no pudo ser entregada por extravío. Habría, entonces, reclamación de la cosa primariamente debida en cualquier caso, y restitución de lo pagado por ella sólo cuando dicho extravío fuese imputable al deudor.

El verdadero sentido del cambio introducido por Bello en la redacción inicial del artículo 1675 desmiente esta conclusión, y va en refuerzo de la explicación aquí ofrecida. Para éste, una de las notas delimitadoras del tiempo que denomina "modo subjuntivo hipotético" es que la condición en que consiste sea un elemento esencial de la frase, de manera que el modo se base precisamente en esa condición y no en sus consecuencias ${ }^{48}$. En cambio, cuando "[1]o que se presenta como condición es a menudo una premisa que se supone alegada o concedida, y de que se saca lógicamente una consecuencia [...], las formas indicativas son las que naturalmente se emplean" ${ }^{\prime 9}$. Precisa también Bello que en los casos en que la hipótesis no es anunciada por la partícula "si", siempre es posible la sustitución del subjuntivo común al hipotético ${ }^{50}$. Bien mirado, el artículo 1675 presenta una estructura que refleja la existencia de una circunstancia de ocurrencia potestativa (de ahí el uso de "podrá" con que se introduce la facultad del acreedor) que se hace depender de un hecho futuro, como es que el acreedor esté dispuesto a restituir lo que hubiera recibido en razón del precio. Ahí el tiempo utilizado sirve para remarcar una especial incidencia en la futuridad de ese hecho, matiz éste que no se lograría con el uso del pretérito pluscuamperfecto de igual modo (como ocurría en el "Proyecto de 1853"), cuya referencia temporal no es inequívocamente futura, sino que se puede referir también al presente o incluso al pasado ${ }^{51}$ (aunque el uso actual tiene a asimilar las funciones de ambos tiempos, que bien pueden describir indistintamente situaciones presentes o pasadas que se consideran hipotéticas ${ }^{52}$ ).

Estas explicaciones de orden semántico inducen a concluir que el cambio observado entre las dos redacciones del artículo 1675 CC. en su fase de preparación responden más bien a un deseo estilístico enderezado a la precisión lingüística de la formulación normativa, pero sin incidencia sobre el sentido y alcance de la facultad ahí conferida al acreedor. La elección del

\footnotetext{
${ }^{48}$ Ibíd., p. 381, nota xiv.

${ }^{49}$ Ibíd., núm. 667 (p. 192).

${ }^{50}$ Ibíd., núm. 660 (p. 189).

${ }^{51}$ Ramírez Luengo, Notas sobre el futuro de subjuntivo, cit. (n. 5), pp. 19-20.

${ }^{52}$ Real Academia Española, Nueva gramática, cit. (n. 4), p. 460.
} 
futuro perfecto de subjuntivo, en reemplazo del pretérito pluscuamperfecto de igual modo, demuestra que Bello estimaba más adecuado concebir el pago en equivalente hecho por el deudor como un supuesto de hipotético acaecimiento, dado que lo lógico es pensar que el deudor se ha conducido diligentemente (artículo 1547 CC.) y de buena fe (artículo 1546 CC.) durante la ejecución del contrato y que, por consiguiente, el extravío ha sobrevenido fortuitamente y con un efecto liberatorio cabal (artículo 1670 CC.). En el empleo de este tiempo hay coincidencia, además, con lo que era un uso asentado en los documentos legales o administrativos de la época (y todavía hoy), cuya redacción facilita la aparición frecuente de estructuras propicias para ser construidas en futuro de subjuntivo, como ocurre con las oraciones condicionales reales (aquellas que se presentan como de cumplimiento posible, en las que piensa Bello al conceptualizar este tiempo) y las oraciones de relativo de carácter generalizador (clase en la que más propiamente se incardina la fórmula empleada en el artículo 1675, al igual que ocurre con las reglas prohibitivas $)^{53}$. En suma, el verdadero propósito existente detrás de la corrección del tiempo verbal utilizado en la redacción del artículo 1675 fue querer indicar que esa frase subordinada comportaba una condición de cuya ocurrencia dependía la pretensión concedida al acreedor, de suerte que éste sólo podía reclamar la cosa propiamente debida en la medida que restituyere aquello que el deudor dio por ella ${ }^{54}$.

Otra apostilla previa atañe a la función extintiva que desempeñan la ejecución forzada y la indemnización de daños respecto de la obligación incumplida ${ }^{55}$. Ambos remedios tienen por objeto obtener del deudor o la misma prestación debida y todavía no ejecutada, o una suma equivalente que satisfaga el interés del acreedor. Es verdad que, tratándose del remedio indemnizatorio, el deudor debe enterar no sólo el valor de la prestación incumplida (aestimatio rei), sino también aquella suma destinada a resarcir los daños causados en el interés de indemnidad del acreedor (id quod interest); pero esta segunda partida no desvirtúa que la indemnización tenga como umbral mínimo el precio de aquello que el deudor debía dar, hacer o no hacer en virtud del contrato. De esta guisa, la extinción de la obligación que comportan estos dos remedios se puede calificar como de tipo satisfactoria

${ }^{53}$ Herrero Ruiz de Loizaga, Cronología y usos del futuro de subjuntivo, cit. (n. 4), p. 946; Real Academia Española, Nueva gramática, cit. (n. 4), pp. 459-460.

${ }^{54}$ Ciertamente, en este cambio influyó además la variedad de español hablada por Bello (véase, más arriba, II).

${ }^{55}$ Sobre una y otra, respectivamente: Pugliatti, Esecuzione forzata, cit. (n. 44), núm. 3, pp. 10-16; y Pizarro Wilson, C., La responsabilidad contractual en Derecho chileno, en Mantilla, F. - Ternera, F. (editores), Los contratos en el Derecho privado (Bogotá, Legis Editores, 2007), pp. 210-212. 
y onerosa, dado que aquélla se produce, directa o indirectamente, como consecuencia de la satisfacción del interés de cumplimiento del acreedor generada por la prestación de reemplazo ejecutada por el deudor. Ambas partes han visto cumplidas, de una u otra forma, las prestaciones con cuyo fin contrataron y, por consiguiente, aquello que se ha dado por la obligación originalmente incumplida se mira como un desplazamiento patrimonial causalmente justificado por el contrato.

Esta misma razón permite concluir que el artículo $1675 \mathrm{CC}$. no es aplicable cuando el acreedor ha optado por la resolución contractual ${ }^{56}$. El artículo 1489 CC. se limita a reconocer que el acreedor tiene la facultad de resolver el contrato en caso de incumplimiento, dando por supuestos los efectos que se siguen de su ejercicio. De su redacción sólo se desprende que la facultad resolutoria entraña dos consecuencias: un efecto liberatorio, que queda comprendido en el poder jurídico reconocido al acreedor ante el incumplimiento ("podrá el otro contratante pedir a su arbitrio [...] la resolución") y un efecto resarcitorio, dado que conjuntamente con la resolución o con la pretensión de cumplimiento aquél puede solicitar la indemnización de cualquier daño sufrido "[...] con indemnización de perjuicios"). Sin embargo, este último no es propiamente una consecuencia derivada de la resolución, sino un remedio autónomo basado en el daño que el incumplimiento ha irrogado al acreedor y que puede ser imputado subjetiva y objetivamente a la esfera de control del deudor (artículos 1556 y 1558 CC.). De ahí que, en puridad, la facultad resolutoria sólo traiga aparejada la extinción del contrato incumplido, sin perjuicio de las restituciones que quepa realizar si han existido desplazamientos patrimoniales anteriores ${ }^{58}$. Dicha extinción no tiene, por tanto, una connotación onerosa (aunque sí satisfactoria), pues el deudor nada ha debido desembolsar y las restituciones que eventualmente realice responden a la necesidad de evitar el enriquecimiento injusto que se

${ }^{56}$ Vial DEL Río, V., Manual, cit. (n. 25), núm. 130, p. 379, considera que el artículo 1675 CC. es también compatible con la resolución por incumplimiento. Así, de reaparecer la cosa debida, el deudor tiene la obligación de venderla en el mismo precio que se pagó por ella como consecuencia de la resolución.

${ }^{57}$ Una de las acepciones admitidas para el verbo "resolver" es "deshacer, destruir". Cfr. Real Academia Española, Diccionario de la lengua (21 a edición, Espasa-Calpe, Madrid, 1992), II, voz “resolver”, p. 1263 (5a acepción).

${ }^{58} \mathrm{La}$ extinción de las obligaciones nacidas del contrato incumplido es una consecuencia del carácter de condición resolutoria que asigna a este remedio el artículo 1489 CC. En efecto, dado que "[e]n los contratos bilaterales va envuelta la condición resolutoria de no cumplirse por uno de los contratantes lo pactado" (artículo 1489), lo lógico es pensar que tal calificación conlleva, al menos, la eficacia extintiva que los artículos 1479 y $1567 \mathrm{~N}^{\circ} 9$ CC. atribuyen al evento de esa forma de condición. 
produciría si el contratante cumplidor se ve privado de aquello que dio en ejecución de contrato y, a la vez, de la prestación esperada.

b) Dicho esto, resta por analizar los equivalentes funcionales de pago de que trata el título $19^{\circ}$ del libro IV CC.

i) El primer caso que interesa considerar es aquel en que el cuerpo cierto debido perece por culpa o durante la mora del deudor (artículo 1672 inciso $1^{\circ} \mathrm{CC}$.) o de alguna de las personas de quienes éste fuera responsable (artículo 1679 CC.); o bien cuando tal perecimiento es producto de un caso fortuito respecto del cual aquél se ha hecho responsable (artículos 1547 inciso $4^{\circ} \mathrm{y}$ 1673 CC.), que no habría sobrevenido de haberse encontrado la especie en poder del acreedor (artículos 1546 inciso $3^{\circ}$ y 1672 inciso $2^{\circ} \mathrm{CC}$.) o del que tiene que responder por haber hurtado o robado la cosa (artículo 1676 CC.). Cuando la pérdida se debe a cualquiera de estas causas, el deudor queda obligado al precio de la cosa y a indemnizar al acreedor los perjuicios causados (artículo 1672 CC.).

Es perfectamente posible que el deudor ignore si la cosa debida verdaderamente existe por un comportamiento negligente. Así ocurre, por ejemplo, cuando una casa de remates ha embalado equivocadamente el cuadro comprado por Ticio y lo ha enviado a una bodega situada en otra ciudad, en espera de que llegue el momento oportuno para subastar la obra supuestamente contenida en el embalaje erróneo. La casa de remates ha sido negligente en su actuar, porque toda obligación de entregar un cuerpo cierto exige la de conservarlo con la diligencia debida (artículos 1548 y 1549 CC.), obligación que implica cuidar de su permanencia en todos los sentidos, comenzando por saber cuál es su actual paradero. Lo mismo acaece si el deudor no ha adoptado todas las medidas de precaución que son esperables para proteger la especie que ha de entregar, y antes del vencimiento del término estipulado para ello, ésta es robada por personas desconocidas. El deudor ciertamente tendrá que responder por su comportamiento culpable, pero puede suceder que con posterioridad la especie sea habida por la policía y le sea restituida (artículos 59 inciso $1^{\circ}$ y 189 CPP.). El acreedor, entonces, puede perfectamente pretenderla en virtud del artículo 1675 CC., restituyendo aquello que recibió por ella en su momento.

ii) También puede suceder que la cosa perezca y el deudor tenga acciones o derechos contra aquellos a cuyo hecho o culpa es imputable el perecimiento. En tal caso, el acreedor puede exigir al deudor que le ceda esas acciones o derechos (artículo 1677 CC.), y se entiende que esa cesión cumple una función equivalente a la del pago (arg. ex artículo 1590 inc iso $3^{\circ} \mathrm{CC}$. $)^{59}$. Si con posterioridad la cosa reaparece, el acreedor puede reclamarla con funda-

${ }^{59}$ AlCalde Silva, J., El “commodum repraesentationis” del artículo 1677 CC., en 
mento en el artículo 1675 , siempre que esté dispuesto a restituir lo obtenido con la cesión del elemento representativo efectuada en su oportunidad por el deudor.

iii) En fin, puede acontecer que la cosa debida se destruya por un hecho voluntario del deudor, pero que éste inculpablemente ignorase su calidad. Si así ocurre, el deudor sólo queda obligado al precio de la cosa (artículo 1678 CC.). Esta regla es importante porque permite sostener que por el solo hecho del contrato el deudor garantiza al acreedor que obtendrá su prestación o su equivalente pecuniario, sin importar que éste subjetivamente y de buena fe ignore que se halla obligado a ello ${ }^{60}$. Asimismo, la regla ayuda a comprender que la vinculación contractual comporta por sí sola un fundamento suficiente de asignación de riesgos, cuya mayor o menor extensión vendrá dada por la previsibilidad añadida al hecho de saberse obligado (artículo $1558 \mathrm{CC}$.) ${ }^{61}$.

$\mathrm{Al}$ efecto es interesante observar la variación experimentada por este artículo en los proyectos de Código Civil, porque hasta el "Proyecto Inédito" esta hipótesis de perecimiento era considerada equivalente a la culpa, aunque con una minoración de la indemnización debida (artículos 7 del título $18^{\circ}$ del "Proyecto de 1842", 184 del "Proyecto de 1847" y 1861 del "Proyecto de 1853 ”). Desde este último ya se observa la redacción definitiva que hoy se contiene en el código (artículo 1861). Los cambios de redacción parecen indicar que el hecho propio del deudor y la hipótesis de la que trata el artículo 1678 son situaciones diversas entre sí o, al menos, que entre ellas no existe una cabal coincidencia. El hecho del deudor es compresivo de todo aquel ámbito de riesgo contractual que éste ha asumido convencionalmente o que ha sido legalmente puesto de su cargo, el que se mira como equivalente a la culpa (entendida ésta como expresión técnica de imputabilidad, y no como falta de la diligencia debida ${ }^{62}$. En cambio, el artículo 1678 trata de la destrucción

Revista de Derecho de la Pontificia Universidad Católica de Valparaíso, 31(2008), pp. 37-161.

${ }^{60}$ En Dig. 36, 1, 25, 2, el fundamento de esta regla es evitar que el hecho de uno cause perjuicio a otro.

${ }^{61}$ Barrientos Zamorano, M., Sobre la previsibilidad en la indemnización de perjuicios y el caso fortuito en materia contractual, en AlCALDE, E. - FÁBREGA, H. (coordinadores), Estudios jurídicos en homenaje al profesor Pablo Rodriguez Grez (Santiago, Ediciones de la Universidad del Desarrollo, 2009), pp. 270-271, después de reseñar el origen histórico del artículo $1558 \mathrm{CC}$., explica que son los meros incumplimientos, sean culposos o no, los que dan lugar a la reparación de los perjuicios que se previeron o pudieron preverse al tiempo del contrato, dado que el elemento utilizado por la norma para establecer tal atribución es la ausencia de dolo, que no necesariamente coincide con el concepto técnico de culpa (artículo 44 CC.).

${ }^{62}$ Cuena Boy, F., "Rerum natura”, cit. (n. 9), pp. 187-188 y 194-222, con referencias bibliográficas en nota 381 . 
de la cosa debida por parte de un deudor que se encontraba de buena fe y en ignorancia justificable de existir la obligación, mientras era dueño y señor de la $\operatorname{cosa}^{63}$. El deudor ignora, en consecuencia, que ostenta esa calidad, sin que concurra negligencia de su parte y sin que exista el deber de saber que tal obligación existía $^{64}$. Habrá tal, por ejemplo, cuando un heredero destruye la cosa que ha sido legada a un tercero por desconocimiento del testamento ${ }^{65}$, o cuando lo hace ignorado que el causante (y él mismo como sucesor) tenía la obligación de darla por cualquier otro título ${ }^{66}$. En estos casos se está en presencia de un hecho que ciertamente puede ser atribuido al deudor por el solo mérito de encontrarse contractualmente obligado a una prestación (artículo 1545 CC.), pero que produce efectos distintos en razón de que aquél desconocía el alcance de dicha vinculación ${ }^{67}$. El conocimiento o la ignorancia del deudor nada tienen que ver con el objeto de la prestación, ya que aquello sobre lo que recae es el hecho mismo de la obligación, vale decir, el dato cierto de su existencia o, si se quiere ser más preciso todavía, el dato de la conexión entre la obligación y un objeto determinado que pertenece al deudor ${ }^{68}$.

\section{El acreedor ha de reclamar la cosa con posterioridad a su reaparición.}

Aunque resulte evidente, el supuesto mencionado en el artículo 1675 sólo recibe aplicación si el acreedor decide reclamar la cosa reaparecida. Para que pueda hacerlo, debe tener conocimiento de que ella ha sido encontrada y se encuentra en manos del deudor o de un tercero. Si la cosa permanece todavía en poder del primero, el acreedor exigirá su entrega conforme al mentado artículo 1675. En cambio, cuando ella ha pasado a manos de un tercero y éste puede legítimamente retenerla para sí, aquél solamente podrá exigir la cesión de las acciones y derechos que el deudor tiene respecto de ese tercero merced el artículo 1677 CC., sin que importe que se haya pagado previamente el valor de prestación (el que, ciertamente, deberá ser restituido). Se trata, por consiguiente, de una facultad concedida exclusivamente a favor del acreedor, quien puede exigir la cosa reaparecida o bien retener legítimamente aquello que ha recibido en razón de su precio, según cual fuere su interés concreto.

${ }^{63}$ Fueyo Laneri, F., Derecho civil, cit. (n. 24), IV, 2, núm. 616, p. 204.

${ }^{64}$ Vial del Río, V., Manual, cit. (n. 25), núm. 130, p. 378.

${ }^{65}$ Delvincourt, Cours de Code Civil, cit. (n. 17), II, p. 586.

${ }^{66}$ Barcia LehmanN, Lecciones, cit. (n. 25), III, núm. 98, p. 198; Barros Errázuriz, A., Curso, cit. (n. 25), II, 1núm. 196, p. 273; Meza Barros, R., De las obligaciones, cit. (n. 26), núm. 684, p. 227; Vial Del Río, V., Manual, cit. (n. 25), núm. 130, p. 378.

${ }^{67}$ Vial del Río, V., Manual, cit. (n. 25), núm. 130, p. 378.

${ }^{68}$ Cuena Boy, F., "Rerum natura”, cit. (n. 9), p. 163. 
De esto se sigue que el deudor no puede ofrecer la cosa al acreedor y exigir que le restituya lo que en su momento dio en razón de su precio, porque sólo a éste corresponde reclamar el bien originalmente debido.

Conviene recordar que el Código Civil contiene ciertas reglas destinadas a disciplinar la suerte de una cosa al parecer perdida cuando ella es hallada por un tercero. Quien la encuentre, debe ponerla a disposición de su dueño; y si nadie se presenta como tal, habrá de entregarla a la autoridad competente (la municipalidad del lugar), la cual deberá dar aviso del hallazgo en un diario de la comuna o de la capital de provincia o de la capital de la región, si en aquélla no lo hubiere (artículo 629 inciso $1^{\circ}$ CC.). Si el dueño no comparece, el aviso se repetirá en dos ocasiones, mediando treinta días entre un aviso y otro (artículo 629 inciso $3^{\circ}$ CC.). De no presentarse dentro del mes subsiguiente al último aviso ninguna persona que justifique su dominio, se venderá la especie en pública subasta; se deducirán del producto las expensas de aprensión, conservación y demás que incidieren; y el remanente se dividirá por partes iguales entre la persona que encontró la especie y la municipalidad respectiva (artículo 630 CC.) ${ }^{69}$. Ciertamente es posible que el dueño aparezca con posterioridad y reclame para sí la cosa encontrada. En ese caso, ésta le será restituida, pagando las expensas, y lo que a título de salvamento adjudicare la autoridad competente al que encontró y denunció la especie (artículo 632 CC.). Si el dueño hubiere ofrecido recompensa por el hallazgo, el denunciador elegirá entre el premio de salvamento y la recompensa ofrecida (artículo 632 CC.).

Para lo que ahora interesa, este procedimiento tiene dos consecuencias importantes. La primera de ellas es que la persona que hubiera omitido las diligencias dirigidas a dar con el dueño o poner la cosa a disposición de la municipalidad correspondiente, perderá su porción a favor de esta última, y aun quedará sujeta a la acción de perjuicios, y según las circunstancias, a la pena de hurto (artículo 631 CC.). La segunda consecuencia atañe al dominio de la especie que no obstante su pérdida seguía conservando su dueño: subastada la especie, se mirará como irrevocablemente perdida para éste (artículo 633 CC.).

El tercero que encuentra una especie al parecer perdida tiene el deber de dar con su dueño y devolvérsela, o bien acudir a la municipalidad del lugar y entregarla ahí. Si no lo hace, su posesión sobre la cosa es de mala fe (artículo 706 CC.) y entraña consecuencias tanto civiles como penales, pudiendo el dueño recuperar aquélla mediante el ejercicio de las acciones correspondien-

${ }^{69} \mathrm{Si}$ la especie fuere corruptible o su custodia y conservación dispendiosas, la subasta puede ser anticipada, y el dueño, presentándose antes de expirar el mes subsiguiente al último aviso, tendrá derecho al precio, deducidas las expensas y el premio de salvamento (artículo 634 CC.). 
tes (artículo 631 CC.). Si el dueño sabe quién tiene la cosa con la que no ha podido cumplir por su extravío, no concurre ni el supuesto del artículo 1670 ni el del artículo 1675. En el primer caso, el deudor es responsable del incumplimiento, porque aunque la cosa haya efectivamente desaparecido de su ámbito de control, sabe dónde puede ser habida. Por idéntica razón, tampoco cabe hablar de reaparición de una cosa cuya existencia se ignoraba, dado que el deudor siempre tuvo conocimiento de que ella estaba en manos de un tercero, contra quien no ha querido ejercer las acciones que le incumben como dueño. Al mismo tiempo, por no haber sobrevenido una pérdida efectiva, tampoco tiene cabida la cesión del commodum repraesentationis (artículo 1677 CC.).

Producida la subasta, la cosa es adquirida por el comprador y se pierde irremisiblemente para su anterior dueño (artículo 633 CC.). Si éste desea recuperarla, podrá intentar adquirirla del nuevo dueño; pero entonces no existe reaparición en el sentido del artículo 1675, sino una adquisición en la que ha mediado un título y un modo que lo han convertido en dueño por segunda vez. Esto significa que el acreedor no podrá reclamar la cosa para sí después de que el deudor la haya adquirido nuevamente, y deberá contentarse con lo que hubiese recibido en razón de su precio.

Un aspecto que el Código no aclara es el plazo dentro del cual la cosa debe reaparecer para que el acreedor pueda hacer uso de la facultad concedida en el artículo 1675 CC. o, puesto en otros términos, desde cuándo la cosa se entiende irremisiblemente perdida para él con independencia de su posterior hallazgo. Cuestión distinta es el plazo que tiene el acreedor para reclamar la cosa desde que ha tenido conocimiento de su reaparición, de la que se tratará más adelante ${ }^{70}$. Aunque el código nada dice sobre el particular, la situación guarda estrecha relación con otra de la que sí se ocupa, como es la interrupción de la prescripción adquisitiva.

El artículo 2502 CC. contempla dos casos de esta clase de interrupción, cada uno de ellos con un efecto distinto.

a) El primero consiste en que, sin haber pasado la posesión a otras manos, se ha hecho imposible el ejercicio de actos posesorios, como cuando una heredad ha sido permanentemente inundada; y su efecto es descontar todo el tiempo de duración de ese impedimento. El ejemplo con el que el Código ilustra esta forma de interrupción natural recibe también una atención especial dentro del título dedicado a la accesión (libro II, Título $5^{\circ}, \S 2$ ). Ahí se dice que si una heredad ha sido inundada, el terreno restituido por las aguas dentro de los cinco años subsiguientes, volverá a sus antiguos dueños (artículo 653). El criterio adoptado coincide, entonces, con el plazo de prescripción

${ }^{70}$ Véase, más abajo, IV, 2, b). 
adquisitiva ordinaria de los inmuebles (artículo 2508 CC.), lo que indica que todo impedimento al ejercicio de la posesión por más de aquel lapso que se estima razonable para la consolidación de una determinada situación fáctica trae consigo la pérdida definitiva de ese estado. Así ocurre con la condición de cuyo cumplimiento depende la restitución de un fideicomiso, que se reputa fallida si tarda más de cinco años en acaecer (artículo 739 CC.); y con la prescripción extintiva de las acciones ordinarias (artículo 2515 CC.). De esto se sigue que toda situación irregular o que genere incertidumbre sobre sus efectos debe quedar saneada al cabo de un cierto tiempo por una necesaria exigencia de seguridad en el tráfico, y la facultad excepcional conferida a un acreedor ya satisfecho en equivalencia no puede recibir un tratamiento distinto. Aunque el Mensaje que precede al código señale que el plazo que otorga seguridad a las posesiones y al crédito es de treinta años $(\$ 41)$, cabe admitir que las sucesivas reformas a las reglas sobre prescripción conducen hoy a una solución distinta. Según el sistema actual del Código Civil, el plazo de clausura de todas las situaciones inciertas es de cinco años, a menos que alguna razón especial justifique el establecimiento de un plazo mayor (como acaece con la prescripción adquisitiva extraordinaria). Si esto es así, la facultad de reclamar la propia cosa debida caduca si ésta no reaparece en el plazo de cinco años contados desde que la obligación se hizo exigible ${ }^{71}$.

b) El segundo caso de interrupción natural mencionado por el artículo 2502 ocurre cuando la posesión se ha perdido por haber entrado en ella otra persona (artículo 726 CC.), de la que se sigue la pérdida de todo el tiempo transcurrido hasta ese momento, a menos que el primer poseedor logré recuperar legalmente la posesión por medio de alguna de las acciones posesorias reguladas por el Código Civil. Propiamente, este supuesto no casa con el concepto de extravío dado por el artículo 1670 CC., que sólo señala que el cuerpo cierto se entiende también perecer cuando "desaparece y se ignora si existe", sin que tal desaparición esté conectada necesariamente con su hallazgo y detentación por otro. Más bien de su redacción se extrae

${ }^{71}$ También es posible concebir otras fórmulas de cómputo del plazo. En efecto, éste puede comenzar a contarse: $i$ ) desde el extravío de la cosa, pues el artículo 1675 parte del supuesto de su reaparición; ii) desde que el deudor toma conocimiento de la desaparición, dado que entonces puede adoptar las medidas para buscar la cosa y, eventualmente, de hallarla, cumplir con ella; o iii) desde que el deudor da algo en razón del precio de la cosa perdida, porque la reclamación de la prestación originaria va conectada inseparablemente a la restitución de lo pagado por ella. Sin embargo, el criterio basado en la exigibilidad parece un parámetro más seguro y no presenta las dificultades de prueba de las dos primeras situaciones, ni el equívoco de la tercera respecto del plazo de prescripción de la propia pretensión de reclamación. 
la conclusión contraria, vale decir, que la cosa se reputa pérdida porque no se sabe si todavía existe materialmente.

\section{LOS PROBLEMAS QUE PLANTEA LA APLICACIÓN DE LA REGLA DEL ARTíCULO 1675 CC.}

Queda por referir los problemas que plantea la aplicación del artículo 1675. Como ha quedado dicho, la norma parte del supuesto de que la cosa debida por el deudor, cuya existencia se ignoraba, ha reaparecido con posterioridad a que éste ha cumplido con su obligación en equivalente. Cuando ello acaece, el acreedor puede reclamar la misma cosa en que la prestación originalmente consistía (2), siempre que restituya lo que hubiere recibido en razón de su precio (3). Ciertamente, desde el punto de vista dogmático, esto requiere o que la obligación resucite o bien que haya permanecido en suspenso durante el tiempo intermedio entre el pago en equivalente y la reclamación de la especie debida (1).

\section{La suerte de la obligación con posterioridad al cumplimiento en equiva-} lente del deudor.

Reaparecida la cosa debida, lo normal es pensar que ella permanece en el patrimonio del deudor, dado que éste ha dado al acreedor algo equivalente en razón de su precio. El Código Civil, empero, atribuye a esa reaparición un efecto exactamente contrario. La duda que surge al leer el artículo 1675 atañe a la suerte que ha tenido la obligación en el tiempo intermedio y al título en virtud del cual se operan las restituciones mutuas ahí prescritas. Dicho de otra forma, hay que aclarar si la obligación se ha extinguido por efecto del cumplimiento en equivalente hecho por el deudor y, en consecuencia, si ella resucita al reaparecer la cosa cuya existencia se ignoraba; o, por el contrario, si la obligación ha permanecido en suspenso durante todo el tiempo intermedio entre dicho cumplimiento y la reaparición de la cosa debida. La solución que se dé a este problema tendrá incidencia a la hora de determinar cuál es el título conforme al cual se produce la entrega de la cosa debida por parte del deudor y de lo que se hubiere recibido en razón de su precio por parte del acreedor. Si se considera que la obligación se extinguió irreversiblemente al consumarse el pago de aquello que el deudor dio al acreedor en reemplazo de la cosa extraviada, el título de la restitución no puede ser otro que la ley. En cambio, si se sostiene que la obligación o ha permanecido en suspenso ${ }^{72}$

${ }^{72}$ Bravo, De la pérdida, cit. (n. 22), p. 29; Claro Solar, L., Explicaciones, cit. (n. 8), XII, núm. 1899, p. 569; García Montero, La imposibilidad, cit. (n. 25), núm. 39, pp. 51-52. 
o bien ha resucitado ${ }^{73}$, el título será el propio contrato del cual nació la obligación de entrega de la cosa ahora encontrada.

Todo parece indicar que el Código Civil sustrae el supuesto del artículo 1675 de aquellos casos de desaparición de la cosa debida que comportan una extinción irreversible de la obligación del deudor (artículos 1567 núm. $7^{\circ}$ y 1670). Como ya ha quedado establecido, el código entiende que la cosa debida perece cuando ella "desaparece y se ignora si existe". Sin embargo, el efecto liberatorio que se sigue de esta forma de perecimiento es sin perjuicio de las excepciones contenidas en el propio título $19^{\circ}$ del libro IV, de donde resulta que hay que distinguir una desaparición que sí tiene efectos extintivos (artículo 1670 CC.) de otra que no los produce (artículo 1675 CC.). En los demás casos enumerados entre los artículos 1672 y 1678 CC., la extinción de la obligación es consecuencia de que el deudor ha satisfecho el precio de la cosa perdida y el importe de los daños sufridos por el acreedor, si la imposibilidad ha sido culpable, mientras que en el supuesto del artículo 1675 CC. tal efecto no acaece o, si que quiere, sólo ocurre con una eficacia condicional. Cuando la cosa se ha extraviado y existe ignorancia sobre su paradero, el cumplimiento en equivalente del deudor está destinado a satisfacer por vía refleja el interés del acreedor. Pero tal cumplimiento, aunque tenga una finalidad extintiva, lleva ínsita la condición de que la cosa directamente debida pueda reaparecer y el acreedor reclamarla, si asílo estima oportuno. La incertidumbre sobre ese hecho hace que la vinculación contractual no se extinga con el cumplimiento en equivalente efectuado por el deudor, y que el efecto de este último sólo sea la creación de una situación de liberación temporal fundada en que el interés específico del acreedor presumiblemente todavía existe, con subsistencia del contrato incumplido por la imposibilidad física de prestar.

En propiedad, el efecto general de la pérdida de la especie o cuerpo cierto debido es la cesación de la obligación de hacer la entrega, puesto que no se puede dar lo que no existe, sin que el contrato en sí se vea afectado en cuanto mecanismo de distribución de riesgos entre los contratantes ${ }^{74}$. Esto explica que, en los contratos bilaterales, el acreedor no quede liberado de pagar el

${ }^{73}$ Alessandri Rodríguez, A., , cit. (n. 26), p. 472; Barcia Lehmann, Lecciones, cit. (n. 25), III, núm. 99, p. 200; Barros Errázuriz, A., Curso, cit. (n. 25), II, 1, núm. 201, p. 280; Fueyo Laneri, F., Derecho civil, cit. (n. 24), IV, 2, núm. 613, p. 198; Meza Barros, De las obligaciones, cit. (n. 25), núm. 691, p. 228; Vial Del Río, V., Manual, cit. (n. 25), núm. 130, p. 379; Vodanovic Haklicka, A., Curso de Derecho civil, III: De las obligaciones (basado en las explicaciones de los profesores Arturo Alessandri Rodríguez y Manuel Somarriva Undurraga, Santiago, Editorial Nacimento, 1941), núm. 726, p. 434.

${ }^{74}$ EsCriche y MARtín, J., Diccionario razonado de legislación y jurisprudencia (Paris, Librería de Rosa Bouret y Cía., ed. corregida por Juan B. Guim, 1852), voz "pérdida”, p. 1343. 
precio convenido (artículo 1550 CC.), y que tampoco pueda pedir su repetición si ya lo hubiese hecho. Pero justifica también que el contrato mantenga su imperio en aquellas situaciones en que la cosa se reputa perdida y respecto de las cuales existe un equivalente funcional que permita reemplazarla. De esa forma, la eficacia extintiva que naturalmente debería corresponder al pago en equivalente queda en suspenso por el propio carácter contingente de un supuesto reversible de imposibilidad, como es el extravío de la cosa objeto de la prestación.

\section{El contenido y alcance de la reclamación del acreedor.}

Además de la cuestión relativa a la suerte de la obligación en el período que media entre el cumplimiento por equivalente y aquel en que se exige la entrega de la cosa reaparecida, el artículo 1675 plantea otros tres problemas relacionados con esa reclamación del acreedor, como son su naturaleza jurídica (a), su plazo de prescripción (b) y sus eventuales límites (c).

a) El rasgo característico de toda obligación civil es que da derecho a exigir su cumplimiento (artículo 1470 inciso $2^{\circ} \mathrm{CC}$.), esto es, permite al acreedor reclamar del deudor la ejecución de la propia prestación debida (artículo 1568 CC.). Este interés específico del acreedor es el que garantiza el artículo 1675 CC., que incluso prescinde del hecho de que ya se haya efectuado un cumplimiento por equivalente de la prestación que se ha tornado imposible por la desaparición de la cosa en que consistía. De ahí, pues, que quepa calificar este derecho como una forma particular de pretensión de cumplimiento, originalmente excluida por la imposibilidad de prestar. Esta pretensión, a diferencia de la relación obligatoria de la que surge, sí revive por efecto de la reaparición de la cosa, dado que el carácter presumiblemente absoluto que se asigna a la desaparición hace que no se pueda estimar que se está ante un caso de imposibilidad temporal que sólo suspende la pretensión de cumplimiento (y la propia eficacia del contrato) mientras dure el obstáculo que impide la entrega ${ }^{75}$. Dicha pretensión se ha ejercido en equivalente y por su intermedio el acreedor ha obtenido aquello que tras la reaparición de la cosa debida debe restituir si la reclama. La comprobación de la existencia de la cosa que se creía absolutamente perdida hace renacer una pretensión que fue agotada al ser ejercida de un modo distinto, cuyo fundamento se halla también en el contrato, pero pone de cargo del acreedor la restitución de aquello que con ella pudo obtener en su oportunidad.

Lo anterior queda más claro si se distingue entre el contenido sustancial y procesal de la pretensión de cumplimiento. Propiamente, esta pretensión tiene por objeto que el deudor ejecute la propia prestación debida (artícu-

${ }^{75}$ Véase, más arriba, III, 2. 
los 1470 inciso $2^{\circ}$ y 1468 CC.), comportamiento esperado que produce la extinción de la obligación (artículo $1567 \mathrm{~N}^{\circ} 1^{\circ} \mathrm{CC}$.). Si bien el acreedor puede aceptar otra cosa distinta en cumplimiento de lo que se le debe (arg. ex artículo 1569 inciso $2^{\circ} \mathrm{CC}$.), tal situación no es relevante en sede de incumplimiento y sólo interesa cuando el programa de prestación tiene un desenvolvimiento normal. Sustancialmente, entonces, la pretensión de cumplimiento es la propia prestación debida que se exige incluso judicial y coactivamente de ser necesario. Pero la ley amplia este alcance en consideración al interés del acreedor, que también puede ser satisfecho a través de una prestación equivalente o mediante el valor de la cosa debida (artículo 438 $\mathrm{N}^{\circ} 2^{\circ}$ y $\mathrm{N}^{\circ} 3^{\circ} \mathrm{CPC}$. $)^{76}$. Así, en la situación descrita en el artículo 1675 CC., la pretensión de cumplimiento ha sido ejercida de acuerdo a su contenido procesal, porque el acreedor ha obtenido del deudor un equivalente funcional de pago. En ese sentido se puede afirmar que la pretensión en cuanto tal ha quedada clausurada por preclusión. Sin embargo, sustancialmente su interés de cumplimiento no ha sido satisfecho más que de un modo reflejo y es lógico que, si la cosa directamente debida reaparece y todavía le interesa, pueda reclamarla mediante el mecanismo idóneo: la pretensión de cumplimiento (ahora ejercida según su contenido sustancial).

b) Es evidente que una facultad como la reconocida al acreedor en el artículo 1675 no puede quedar sujeta a una perpetua indeterminación y que, como toda pretensión, debe tener un plazo de prescripción (artículos 2492 y 2514 inciso $1^{\circ} \mathrm{CC}$.). El problema estriba en determinar cuál es ese plazo y desde cuándo se computa.

La primera cuestión no parece comportar mayores problemas: en ausencia de un término diverso, a la reclamación de que habla la mentada norma se le debe aplicar la regla general del artículo 2515 CC. y, en consecuencia, prescribe al cabo de cinco años.

Más ardua puede ser la segunda de las cuestiones antes mencionadas, relativa al momento en que se inicia el cómputo de dicho plazo, y que exige precisar cuál es la exigibilidad que se ha de tomar en cuenta a efectos de la reclamación que el acreedor puede hacer con fundamento en el artículo 1675 (artículo 2514 inciso $2^{\circ} \mathrm{CC}$.). $\mathrm{Al}$ respecto, tres son las soluciones que comparecen: $i$ ) el plazo se cuenta desde que la obligación originaria es exigible, vale decir, desde el momento en que el acreedor puede pedir el cumplimiento y el deudor se halla en la necesidad de ejecutar aquella prestación que se torna imposible por el extravío de la cosa; ii) los cinco años se computan desde que

${ }^{76}$ Morales Moreno, Antonio Manuel, Pretensión de cumplimiento y pretensión indemnizatoria (2006), ahora en La modernización del Derecho de obligaciones (Madrid, Thomson-Civitas, 2006), pp. 81-92. 
reaparece la cosa cuya existencia se ignoraba, porque ése es el supuesto que activa la regla del artículo 1675; y iii) el término de prescripción comienza con el pago en equivalente que efectúa el deudor, pues con él se ha querido poner término a una relación obligatoria frustrada por la imposibilidad sobrevenida de la prestación. Ahora bien, según lo antes dicho sobre la suerte de la obligación entre la pérdida de la cosa y su reaparición, la primera de estas soluciones es la que mejor cuadra con el esquema general que aquí se ha reconstruido. Si la obligación no se ha extinguido, porque la pérdida que afecta la cosa es de aquellas que (mirada retrospectivamente) no tiene tal efecto, la conclusión lógica es afirmar que la reclamación del deudor es la misma pretensión de cumplimiento (ésta sí rediviva) que se ejerce con el fin de obtener aquello sobre lo que efectivamente se contrató y que, por ende, satisfacía plenamente el interés concreto del acreedor. Además, con esta forma de cómputo se evita una duplicidad de plazos, pues la prescripción de la pretensión del acreedor coincide con el lapso que se considera razonable para la reaparición de la cosa ${ }^{77}$.

c) La reclamación del artículo 1675 está sujeta a los mismos límites que cualquier otra pretensión. Especialmente relevante a estos efectos es la exigencia de un interés legítimo que mediante tal reclamación se desea satisfacer. Claramente, el espíritu de la regla es permitir que el acreedor pueda obtener la misma cosa sobre la que contrató, dado que se entiende que ella es la que satisface en mejor modo el propósito práctico que lo llevó a celebrar el contrato (artículo 1467 CC.). Si es así, la reclamación sólo podrá ser eficaz hasta dónde alcance ese interés, y habrá de ser rechazada si éste ha desparecido o se ha frustrado irremediablemente. Así ocurre, por ejemplo, si la cosa debida era una estatua atribuida a la escuela de Fidias que iba a ser exhibida por un museo en una exposición temporal dedicada al arte de la Grecia clásica, y ella reaparece cuando ésta ya ha finalizado. En estos casos, la indemnización recibida por el acreedor es suficiente compensación por el incumplimiento y su interés, en atención a la naturaleza del contrato y la buena fe (artículo 1546 CC.), no puede alcanzar también la cosa reaparecida.

\section{La restitución de lo que se hubiere recibido en razón del precio de la cosa extraviada}

El artículo 1675 CC. señala, en fin, que el acreedor sólo puede reclamar la cosa originalmente debida si previa o contemporáneamente devuelve " $/ o$ que hubiere recibido en razón de su precio", restitución enderezada a evitar un enriquecimiento injusto de su parte. Aquí el problema consiste en determinar cuál es el contenido de esta devolución.

\footnotetext{
${ }^{77}$ Véase, más arriba, III, 4.
} 
De los casos mencionados precedentemente se desprende que el contenido de lo pagado por el deudor puede corresponder a dos partidas claramente diferenciadas: el valor de la cosa (aestimatio rei) y los daños sufridos por el acreedor (id quod interest). Sin embargo, la naturaleza particular de cada uno de estos rubros no tiene mayor importancia, dado que el Código Civil los considera parte integrante de la indemnización que puede exigir el acreedor ante el incumplimiento (artículo 1556). En efecto, en el artículo 1678 CC. se señala que el deudor sólo queda obligado al pago del precio si la cosa se destruye por un hecho involuntario y durante un estado de ignorancia inculpable sobre la existencia de la obligación, "sin otra indemnización de perjuicios". El código, por consiguiente, añade una partícula que quiere establecer una diferencia con aquello de lo que primeramente se habla, para dejar en claro mediante tal recurso semántico que todo lo que excede el precio de la cosa perdida (daño intrínseco) es considerado también indemnización (daño extrínseco) $)^{78}$.

A estos efectos, el valor de la cosa puede significar tanto el precio de ésta (artículos 1672, 1673, 1676, 1678 y 1679 CC.) como el subrogado que respecto de ella representan los derechos o acciones que el deudor tiene contra los terceros por cuyo hecho o culpa se ha producido el perecimiento (artículo 1677 CC.). En esta clave debe ser leído el artículo 1590 CC., que señala la forma en que se ha de efectuar el pago de una obligación específica. En dicha norma se establece como principio que "[s] i la deuda es de cuerpo cierto, debe el acreedor recibirlo en el estado que se halle" (artículo 1590 iso $\left.1^{\circ} \mathrm{nc}\right)$, siempre que el deterioro no suponga una destrucción de la aptitud de la cosa para el objeto a que según su naturaleza o según la convención se destina (artículos 1486 inciso $3^{\circ} \mathrm{C}$ y 1590 inciso $2^{\circ} \mathrm{CC}$.); lo que no impide que la ley reconozca a su vez el derecho del acreedor a ser indemnizado de los perjuicios derivados de la pérdida parcial (artículo 1590 inciso $2^{\circ}$ ). Tales perjuicios son equivalentes al porcentaje del valor de la especie que comporta el deterioro, según se infiere del hecho de que la ley hace compatibles, como facultades del acreedor, la entrega del residuo y la indemnización. Si la pérdida de la cosa es total, o el deterioro pareciere de importancia, el acreedor puede optar por algunas de las facultades mencionadas en el artículo 1489 CC. y repetidas en sede de pago por el artículo 1590 CC.: exigir el cumplimiento forzoso o resolver el contrato.

Para el acreedor, la consecuencia de optar por alguna de las facultades recién señaladas no desvirtúa la tensión de su derecho de crédito, que seguirá mirando hacia el resultado esperado. Si la obligación se reputa cumplida con la satisfacción del interés del acreedor antes que con la cosa debida, la tensión

${ }^{78}$ Vial del Río, V., Manual, cit. (n. 25), núm. 130, p. 375. 
que ella expresa atiende a un interés a satisfacer, el que se refleja, ante todo, en una cosa idealmente configurada por el contrato, pero que económicamente no es más que un valor patrimonial. Por eso, el Código Civil habla en varias ocasiones del precio de la cosa como su equivalente natural, sobre el que también se puede dirigir la pretensión de cumplimiento (artículo 438 $\mathrm{N}^{\circ} 2^{\circ} \mathrm{CPC}$.) y para cuya obtención no es necesaria la imputación subjetiva del incumplimiento a la esfera de riesgo administrada por el deudor (artículos $621,634,662$ inciso $3^{\circ}, 663$ inciso $2^{\circ}, 910$ inciso $2^{\circ}, 1486$ inciso $1^{\circ}$, 1502 inciso $2^{\circ}, 1504$ inciso $2,1521,1532,1533,1534,1672,1675,1678$, 1743,2084 inciso $3^{\circ}, 2086,2178$ inciso $2^{\circ}, 2198$ y 2230), sino sólo que la prestación sea todavía posible de ejecutar (artículos $1567 \mathrm{~N}^{\circ} 7^{\circ}$ y $1670 \mathrm{CC}$. y 464 excepción $15^{\mathrm{a}} \mathrm{CPC}$. $)^{79}$. La ley asume que el interés del acreedor no está representado generalmente por la prestación a la que se ha obligado el deudor, porque existe en paralelo un amplio mercado de bienes y servicios al cual aquél puede acudir para satisfacer su interés ${ }^{80}$. De ahí que cualquier obligación lleve en sí el germen de convertibilidad de la prestación originalmente debida en una prestación de carácter dinerario consistente en el valor común o de mercado que ella tiene. Esta idea viene anunciada por el artículo 2465 CC., que establece un principio basal para entender el cabal funcionamiento del sistema de protección del crédito: la obligación afecta potencialmente el patrimonio del deudor a la satisfacción de interés del acreedor, de suerte que cualquiera sea el objeto sobre el que primariamente se contrató, aquél tiene siempre la facultad de dirigirse contra los bienes del deudor y obtener en ellos la satisfacción del interés que esperada conseguir al contratar ${ }^{81}$.

Según el artículo 1675 CC., el acreedor que reclame la cosa reaparecida

${ }^{79}$ BARAONa GonzÁlez, J., Algunas consideraciones sobre el retraso en el cumplimiento de las obligaciones: su configuración y eficacia, en Pizarro Wilson, C. (editor), Estudios de Derecho civil (Santiago, LegalPublishing, 2009), IV, p. 377; El mismo, Responsabilidad contractual y factores de imputación de daños: apuntes para una relectura en clave objetiva, en Revista Chilena de Derecho, 34 (1997) 1, pp. 156 y 159-176; Corral Talciani, Hernán, Causalidad y previsibilidad en la responsabilidad contractual, en Vargas Pinto, T. (editor), Cuadernos de extensión jurídica, 15: La relación de causalidad. Análisis de su relevancia en la responsabilidad civil y penal (Santiago, Ediciones de la Universidad de los Andes, 2008), pp. 133-134; Peñailillo Arévalo, Daniel, Responsabilidad contractual objetiva, en Pizarro Wilson, C. (editor), Estudios de Derecho civil (Santiago, LegalPublishing, 2009), IV, pp. 335-336, 338 y 345; PiZARro WILson, Carlos, La responsabilidad contractual, cit. (n. 55), pp. 211-212; VIAL DEL Río, V., Manual, cit. (n. 25), núm. 130, p. 376.

${ }^{80}$ Barros Bourie, E., La diferencia, cit. (n. 37), p. 732.

${ }^{81}$ BetTi, Emilio Teoría general de las obligaciones (trad. de José Luis de los Mozos, Madrid, Editorial Revista de Derecho Privado, 1969), I, pp. 290-291 y 298-310. 
debe previamente restituir "lo que hubiere recibido en razón de su precio", expresión que leída en el contexto del título $19^{\circ}$ del libro IV no puede significar más que alguno de los equivalentes funcionales de pago que antes se han mencionado (artículo 22 CC.). Por eso, es digna de elogio la expresión amplia empleada por el Código, que permite incluir tanto el precio en sí (la cantidad de dinero pagada según el valor de la cosa) como el commodum repraesentationis ${ }^{82}$. En sentido inverso, el acreedor puede retener legítimamente la indemnización pagada por el daño extrínseco que es consecuencia del comportamiento imputable en que se encontraba el deudor al momento de producirse el extravíio ${ }^{83}$, dado que ésta está destinada a compensar su interés de indemnidad, vale decir, a resarcir el daño emergente, el lucro cesante y, eventualmente, el daño moral que aquél pueda haber sufrido (artículos 1556 y 1558 CC. $)^{84}$.

Ahora bien, puede ocurrir que el valor de la cosa reaparecida haya variado en el tiempo intermedio. En principio, las reglas del Código Civil sobre la materia no sugieren que el deudor pueda pedir alguna compensación por el mayor valor, puesto que la obligación consiste en entregar la cosa debida en el estado en que se encuentre, soportando el acreedor los deterioros y aprovechándole las mejoras (artículo 1590 inciso $1^{\circ}$ CC.). En cambio, sí tendrá derecho a exigir que la suma pagada en función del precio sea devuelta debidamente reajustada (arg. ex artículos 854 y 1206 inciso $2^{\circ}$ CC.).

${ }^{82}$ En rigor, la expresión usada por el artículo 1675 debería aludir sólo al valor pecuniario en que se estima la cosa extraviada, que es el sentido natural y obvio del término precio según el uso general que se hace de él. Sin embargo, partiendo del hecho de que el código no hace mención a la entrega de una cantidad de dinero (bien podría haber dicho la suma que hubiere recibido en razón de su precio), se ha preferido interpretar dicha partícula en el contexto del título $19^{\circ}$ del libro IV y ampliar así la posibilidad de que el acreedor pueda satisfacer en naturaleza su interés si la cosa posteriormente reaparece. La misma razón lleva a excluir que aquello que ha dado el deudor pueda consistir en una prestación equivalente a la incumplida por el extravío de la cosa, pues entonces el interés del acreedor vendría satisfecho cabalmente y no correspondería que la tensión de la relación obligatoria se mantuviese todavía latente.

${ }^{83}$ Abeliu K Manasevich, R., Las obligaciones, cit. (n. 38), II, núm. 1202, p. 1058; Barcia Lehmann, Lecciones, cit. (n. 25), III, núm. 99, p. 200; Claro Solar, L., Explicaciones, cit. (n. 8), XII, núm. 1899, p. 570; Meza BARros, R., De las obligaciones, cit. (n. 25), núm. 691, pp. 228-229.

${ }^{84}$ ViAl del Río, V., Manual, cit. (n. 25), núm. 130, p. 379-380, estima que, aunque nada diga la ley al respecto, el deudor puede exigir igualmente la restitución de lo pagado por los perjuicios si la indemnización pareciera excesiva, pues la situación es muy similar a la que se produce con el cumplimiento tardío. 


\section{Conclusiones}

El artículo 1675 CC. permite al acreedor reclamar la cosa directamente debida cuya existencia se ignoraba, siempre que restituya aquello que hubiere recibido en razón de su precio. Es ésta una regla original del Código chileno, sin correspondencia directa en las fuentes legales o doctrinales de las que se sirvió Bello para componer el título $19^{\circ}$ de su libro IV, aunque inspirada en las explicaciones de Pothier sobre el alcance del extravío. Bien mirada, la norma no deja de suscitar perplejidad por el contenido de la facultad que confiere al acreedor: éste puede exigir la prestación debida sin importar que el deudor ya hubiera dado algo en razón de su precio y con una supuesta finalidad extintiva. Por de pronto, esa posibilidad hace que la situación ahí descrita no comporte un caso de extinción de la obligación del deudor, sino sólo una hipótesis de liberación temporal condicionada al eventual hallazgo de la cosa perdida y a la preservación del interés del acreedor en que se cumpla con ella. Hay, entonces, un ejercicio de la pretensión de cumplimiento fundada en el propio contrato con posterioridad a que el acreedor ha recibido algún equivalente funcional de pago y, por ende, de que ha agotado el contenido procesal de esa misma pretensión, que ahora revive en su aspecto sustancial. Dicha facultad, por su carácter excepcional, ha de estar sujeta a ciertos límites temporales y materiales. Respecto de los primeros, existe un plazo de caducidad y otro de prescripción que delimitan su ejercicio, aunque ambos coinciden en su duración y forma de cómputo. En lo que atañe a los segundos, la reclamación exige que todavía persista el interés específico del acreedor por la prestación originaria y que éste restituya lo que hubiere recibido en lugar de la cosa debida. La existencia de este último requisito excluye que el artículo 1675 CC. pueda recibir aplicación cuando la desaparición tiene un origen fortuito, porque en ese caso el acreedor no recibe nada a cambio de su propia prestación (artículo 1550 CC.); y justifica que éste pueda retener legítimamente la suma dada como resarcimiento de los daños irrogados por el incumplimiento, que quedan fuera del equilibrio de prestaciones que la restitución quiere restablecer.

\section{BIBLIOGRAFÍA}

Abeliuk Manasevich, René, Las obligaciones (4ª edición, Santiago, Editorial Jurídica de Chile, 2001), II.

Alcalde Silva, J., El “commodum repraesentationis" del artículo 1677 CC., en Revista de Derecho de la Pontificia Universidad Católica de Valparaíso, 31(2008).

Alessandri Rodríguez, Arturo, Teoría de las obligaciones (reimpresión Santiago, Editorial Jurídica Ediar-ConoSur Ltda., 1988). 
BARAONA GONZÁlez, Jorge, Algunas consideraciones sobre el retraso en el cumplimiento de las obligaciones: su configuración y eficacia, en Pizarro Wilson, C. (editor), Estudios de Derecho civil (Santiago, LegalPublishing, 2009), IV.

BARAONa González, Jorge, Responsabilidad contractual y factores de imputación de daños: apuntes para una relectura en clave objetiva, en Revista Chilena de Derecho, 34 (1997) 1.

Barcia Lehmann, R., Lecciones de Derecho civil chileno, III: De la teoría de las obligaciones (Santiago, Editorial Jurídica de Chile, 2008).

Barrientos Zamorano, M., Sobre la previsibilidad en la indemnización de perjuicios y el caso fortuito en materia contractual, en ALCALDE, E. - FÁBREGA, H. (coordinadores), Estudios jurídicos en homenaje al profesor Pablo Rodriguez Grez (Santiago, Ediciones de la Universidad del Desarrollo, 2009).

BARros Bourie, E., La diferencia entre "estar obligado" y "ser responsable" en el Derecho de los contratos, en Corral, H.- Rodríguez, M. a S. (editores), Estudios de Derecho civil (Santiago, Editorial LexisNexis, 2007), II.

BArros Bourie, Enrique, Finalidad y alcance de las acciones y los remedios contractuales, en Guzmán Brito, A. (editor), Estudios de Derecho civil (Santiago, LegalPublishing, 2008), III.

Barros Errázuriz, Alfredo, Curso de Derecho civil, II, 1: Trata de las obligaciones en general ( $4^{a}$ edición, Santiago, Nascimento, 1932).

Bello López, Andrés, Obras completas, IV: Gramática de la lengua castellana destinada al uso de los americanos (3a edición, Caracas, La Casa de Bello, 1994).

BetTi, Emilio Teoría general de las obligaciones (trad. de José Luis de los Mozos, Madrid, Editorial Revista de Derecho Privado, 1969).

Brantt Zumarán, María Graciela, El caso fortuito y su incidencia en el Derecho de la responsabilidad civil contractual. Concepto y función del caso fortuito en el Código Civil chileno (Santiago, AbeledoPerrot/LegalPublishing, 2010).

Bravo, J., De la pérdida de la cosa que se debe (memoria de prueba para optar al grado de Licenciado en la Facultad de Leyes y Ciencias Sociales de la Universidad de Chile, Santiago, Almacén Librero e Imprenta Jordán, 1922).

Castilla Barea, M., La imposibilidad de cumplir los contratos (Madrid, Dykinson, 2000).

Claro Solar, Luis, Explicaciones de Derecho civil chileno y comparado, XII: De las obligaciones, 3 (Santiago, Nascimento, 1939).

Corral Talciani, Hernán, Causalidad y previsibilidad en la responsabilidad contractual, en Vargas Pinto, T. (editor), Cuadernos de extensión jurídica, 15: La relación de causalidad. Análisis de su relevancia en la responsabilidad civil y penal (Santiago, Ediciones de la Universidad de los Andes, 2008).

Cuena Boy, Francisco, "Rerum natura" e imposibilidad fisica de la prestación en el Derecho romano clásico (Santiago de Compostela, Andavira, 2010).

Delvincourt, C. E., Cours de Code Civil (Paris/Dijon, Videcoq Libraire/Victor Lagier Libraire, 1834), II.

Domat, Jean, Las leyes civiles en su orden natural (Barcelona, Imprenta de José Tauló, 1841).

Escriche y Martín, J., Diccionario razonado de legislación y jurisprudencia (Paris, Librería de Rosa Bouret y Cía., ed. corregida por Juan B. Guim, 1852).

Figueroa YÁÑEz, G. (coordinador), Repertorio de legislación y jurisprudencia chilenas. 
Código Civil y leyes complementarias ( $3^{\text {a }}$ edición, Santiago, Editorial Jurídica de Chile, 1997), VI.

Fuentealba Chávez, D., Estudio sobre el caso fortuito y la fuerza mayor (memoria de prueba para optar al grado de Licenciado en la Facultad de Leyes y Ciencias Políticas de la Universidad de Chile, Valparaíso, Imprenta Porteña, 1919).

Fueyo Laneri, Fernando, Derecho civil, IV, 2: Obligaciones (Santiago, Imprenta y Litografía Universo, 1958).

García Goyena, Florencio, Concordancias, motivos y comentarios del Código Civil español (reimpresión de la edición de Madrid, 1852, al cuidado de la Cátedra de Derecho civil de la Universidad de Zaragoza, Zaragoza, Editorial Cometa, 1974.

García Montero, C., La imposibilidad de ejecución como forma de extinguir las obligaciones (memoria de prueba para optar al grado de Licenciado en la Facultad de Ciencias Jurídicas y Sociales de la Universidad de Chile, Santiago, 1942).

GioRgi, J., Teoria de las obligaciones en el Derecho moderno, VIII: Extinción de las obligaciones (continuación y fin) (trad. de la Redacción de la Revista General de Legislación y Jurisprudencia, $2^{a}$ edición, Madrid, Editorial Reus, 1930).

Guzmán Brito, Alejandro, Andrés Bello codificador. Historia de la fijación y codificación del Derecho civil en Chile (Santiago, Ediciones de la Universidad de Chile, 1982), I.

GuZmán Brito, Alejandro, Destrucción y especificación de una cosa corporal, en GuZMÁn Brito, A. (editor), Estudios de Derecho civil (Santiago, LegalPublishing, 2008), III.

Guzmán Brito, Alejandro, La codificación civil en Iberoamérica. Siglos XIX y XX (Santiago, Editorial Jurídica de Chile, 2000).

Herrero Ruiz de Loizaga, F. J., Cronología y usos del futuro de subjuntivo, en Villayandre Llamazares, M. (editor), Actas del XXV Simposio internacional de la Sociedad Española de Lingüistica (León, Publicaciones de la Universidad de León, 2006).

Lira Urguieta, Pedro, García Goyena y el Código Civil chileno, en El Código Civil chileno y su época (Santiago, Editorial Jurídica de Chile, 1956).

Malaurie, M. a Les restitutions en Droit civil (Paris, Cujas, 1991).

Manresa y Navarro, J. M. a Comentarios al Código Civilespañol (Madrid, Imprenta de la Revista de Legislación, 1901), VIII.

Meza Barros, Ramón, De las obligaciones (10 edición por Pedro Pablo Vergara Varas, Santiago, Editorial Jurídica de Chile, 2007).

Morales Moreno, Antonio Manuel, Pretensión de cumplimiento y pretensión indemnizatoria (2006), ahora en La modernización del Derecho de obligaciones (Madrid, Thomson-Civitas, 2006).

Peñailillo Arévalo, Daniel, Responsabilidad contractual objetiva, en Pizarro WiLson, C. (editor), Estudios de Derecho civil (Santiago, LegalPublishing, 2009), IV.

Pizarro Wilson, Carlos, Hacia un sistema de remedios al incumplimiento contractual, en GuZmán Brito, A. (editor), Estudios de Derecho civil (Santiago, LegalPublishing, 2008), III,

Pizarro Wilson, Carlos, La responsabilidad contractual en Derecho chileno, en MaNtilla, F. - Ternera, F. (editores), Los contratos en el Derecho privado (Bogotá, Legis Editores, 2007).

Pothier, Robert-Joseph, Tratado de las obligaciones (trad. de M. C. de las Cuevas, Sao Paulo, Editorial Heliasta, 1993). 
Pugliatti, S., Esecuzione forzata e Diritto sostanziale (Milano, Giuffrè, 1935.

Ramírez Luengo, J. L., Notas sobre el futuro de subjuntivo en la primera mitad del siglo XIX: el caso de Bolivar, en Estudios de Lingüistica, 15 (2001).

Real Academia Española, Diccionario de la lengua (21 a edición, Espasa-Calpe, Madrid, 1992), II.

Real Academia Española, Nueva gramática de la lengua española. Manual (Madrid, Espasa, 2010).

Rodríguez Grez, Pablo, Extinción no convencional de las obligaciones (Santiago, Editorial Jurídica de Chile, 2008).

Rogron, J. A., Code Civil expliqué (Paris, E. Plon et Cie. Imprimeurs-Éditeurs, 19a ed. por E. Bonnier, 1877), I.

Saint-Joseph, F. A., Concordance entre les codes civils étranger et le Code Napoleon (2a edición, París, Cotillon, Libraire du Conseil d'Etat, 1856), cuatro volúmenes.

Verdera Server, R., El cumplimiento forzoso de las obligaciones (Bolonia, Publicaciones del Real Colegio de España, 1995).

Vial del Río, Víctor, Manual de Derecho de las obligaciones en el Código Civil chileno ( $2^{a}$ edición, Santiago, Editorial Biblioteca Americana, 2007).

Vidal Olivares, Álvaro, El incumplimiento de obligaciones con objeto fungible y los remedios del acreedor. Una relectura de las disposiciones del "Código Civil" sobre incumplimiento, en GuZmán Brito, A. (editor), El Código Civil de Chile (18552005) (Santiago, Editorial LexisNexis, 2007).

Vidal Olivares, Álvaro, La Convención de Viena (CISG) como clave del debate. La visión del jurista americano, en VV. AA., Derecho privado europeo: estado actual y perspectivas de futuro (Jornadas en la Universidad Autónoma de Madrid, 13 y 14 de diciembre de 2007) (Madrid, Thomson-Civitas, 2008).

Vodanovic Haklicka, A., Curso de Derecho civil, III: De las obligaciones (basado en las explicaciones de los profesores Arturo Alessandri Rodríguez y Manuel Somarriva Undurraga, Santiago, Editorial Nacimiento, 1941).

Zuluaga, A., El futuro de subjuntivo. Observaciones sobre la distinción lengua habladal lengua escrita y el verbo español, en BELLINI, G. (editor), Actas del VII Congreso de la Asociación Internacional de Hispanistas (Roma, Bulzoni, 1982). 